\title{
Cytotoxicity evaluation of carbon-encapsulated iron nanoparticles in melanoma cells and dermal fibroblasts
}

\author{
Ireneusz P. Grudzinski • Michal Bystrzejewski • \\ Monika A. Cywinska • Anita Kosmider • Magdalena Poplawska • \\ Andrzej Cieszanowski · Agnieszka Ostrowska
}

Received: 18 July 2012 / Accepted: 2 July 2013/Published online: 24 July 2013

(C) The Author(s) 2013. This article is published with open access at Springerlink.com

\begin{abstract}
Carbon-encapsulated iron nanoparticles (CEINs) are emerging as promising biomedical tools due to their unique physicochemical properties. In this study, the cytotoxic effect of CEINs (the mean diameter distribution ranges $46-56 \mathrm{~nm}$ ) has been explored by MTT, LDH leakage, Calcein-AM/propidium iodide (PI) and Annexin V-FITC/PI assays in human melanoma (HTB-140), mouse melanoma (B16-F10) cells, and human dermal fibroblasts (HDFs). The results demonstrated that CEINs produce mitochondrial and cell membrane cytotoxicities in a dose $(0.0001-100 \mu \mathrm{g} / \mathrm{ml})$-dependent manner. Moreover, the studies elucidated some differences in
\end{abstract}

Electronic supplementary material The online version of this article (doi:10.1007/s11051-013-1835-7) contains supplementary material, which is available to authorized users.

I. P. Grudzinski $(\bowtie) \cdot$ M. A. Cywinska · A. Kosmider Department of Toxicology, Faculty of Pharmacy,

Medical University of Warsaw, ul. S. Banacha 1,

02-097 Warsaw, Poland

e-mail: ireneusz.grudzinski@wum.edu.pl

\section{Bystrzejewski}

Department of Physical Chemistry, Faculty of Chemistry, Warsaw University, ul. L. Pasteura 1, 02-093 Warsaw, Poland

\section{Poplawska}

Department of Organic Chemistry, Faculty of Chemistry, Warsaw University of Technology, ul. S. Noakowskiego

3, 00-664 Warsaw, Poland cytotoxic effects between CEINs used as raw and purified materials composing of the carbon surface with acidic groups. Experiments showed that HTB-140 cells are more sensitive to prone early apoptotic events due to raw CEINs as compared to B16-F10 or HDF cells, respectively. Taken together, these results suggest that the amount of CEINs administered to cells and the composition of CEINs containing different amounts of iron as well as the carbon surface modification type is critical determinant of cytotoxic responses in both normal and cancer (melanoma) cells.

Keywords Carbon-encapsulated iron nanoparticles (CEINs) · Cytotoxicity · Melanoma cells · Dermal fibroblasts

\author{
A. Cieszanowski \\ Department of Clinical Radiology, Faculty of Medicine, \\ Medical University of Warsaw, ul. S. Banacha 1a, \\ 02-097 Warsaw, Poland
}
A. Ostrowska
Analytic Centre, University of Life Sciences SGGW, ul. J. Ciszewskiego 8, 02-786 Warsaw, Poland 


\section{Introduction}

Interest in using magnetic nanoparticles (MNPs) has gained a great deal of attention in the last few years following numerous preclinical studies showing that multifunctional MNPs capable of being imaged using magnetic resonance, and loaded with anticancer drugs have offered attractive possibilities for the future improvement of anticancer therapy in humans (Shubayev et al. 2009; Zhang et al. 2009). One major characteristic of MNPs that has made them a really favorite among cancer researchers and biomaterial nanoscientists in general is the ability to modify their surface with different polymers, ligands, and sitespecific navigated biomolecules (Ahmed et al. 2012; Davis et al. 2010; Yu et al. 2012; Yuan et al. 2012). In this way, a simple nanoparticle becomes a "smart" nanoparticle to be really used as multifunctional controlled drug delivery systems (DDS) for the personalized cancer nanomedicine (Davis et al. 2010; Yu et al. 2012). Therefore, the innovative approaches to controlled DDS using nanotechnology are revolutionizing the future of cancer treatments in clinical nanomedicine (Hosseinkhani 2006; Subramani et al. 2009; Yu et al. 2012).

In recent years, a number of magnetic nanosystems composing of multifunctional nanoparticles harboring various functions including targeting, imaging, stem cell labeling and tracking have been intensively studied aiming to overcome some limitations associated with conventional cancer diagnosis and therapy (Berman et al. 2011; Hosseinkhani et al. 2012; Miele et al. 2012). This strategy was addressed the "find, fight, and follow" concept of early diagnosis, therapy, and therapy control, sometimes also known as "theranostics" (Xie et al. 2010; Liu et al. 2010; Pan et al. 2009). Among different MNPs studied to date, carbonencapsulated iron nanoparticles (CEINs) have recently attracted growing interest as a novel generation of magnetic nanomaterial in biomedical and chemical research (Bystrzejewski et al. 2007, 2011; Taylor et al. 2010; Xu et al. 2011; Zeng et al. 2012). These heterostructural nanoparticles are composed of the iron core (generally of the spherical shape), which is covered by carbon coating. The carbon coating is formulated of highly crystalline and curved graphene layers, which protects the core against any oxidization processes, preserves its specific magnetic properties, and further endows the encapsulated iron nanoparticles with the bio-compatibility and stability in many organic and inorganic media including animal and human fluids (Bystrzejewski et al. 2007, 2011). It should be emphasized that carbon-encapsulated MNPs have been also found to be readily susceptible to chemical and biological functionalization (Grass et al. 2007; Park et al. 2011; Poplawska et al. 2010). This feature has opened exciting avenues for using CEINs as novel "smart" contrast agents in molecular magnetic resonance imaging (mMRI) and targeted drug delivery (nano)systems in preclinical cancer studies (Park et al. 2011; Taylor et al. 2010; Tietze et al. 2012; Yoo et al. 2011).

Along with the expanding interest in MNPs in general their potential toxicity has become one of the major concerns. To date, most research programs in the potent toxicity evaluation of iron nanoparticles have focused mainly on iron oxides, such as magnetite $\left(\mathrm{Fe}_{3} \mathrm{O}_{4}\right)$ and maghemite $\left(\gamma-\mathrm{Fe}_{2} \mathrm{O}_{3}\right)$. A number of studies evidences that specific properties of iron oxide nanoparticles such as enhanced reactive area, ability to cross cell and tissue barriers, resistance to biodegradation, amplify their cytotoxic potential relative to molecular or bulk counterparts (Gupta and Gupta 2005; Safi et al. 2011; Tomitaka et al. 2009; Ying and Hwang 2010). Iron oxide nanoparticles have been found to induce oxidative stress, which manifests in activation of reactive oxygen species, followed by a pro-inflammatory response and DNA damage leading to cellular apoptosis and mutagenesis (Naqvi et al. 2010; Novotna et al. 2012; Zhu et al. 2010). Several pharmacokinetic reports indicate that the liver of laboratory animals is the most important organ involving the bioaccumulation and clearance procedures of the iron oxide nanoparticles studied in preclinical models (Schlachter et al. 2011). In general, ultra-smaller superparamagnetic iron oxide $\left(\mathrm{Fe}_{3} \mathrm{O}_{4}\right)$ nanoparticles, also called as USPIO (under $50 \mathrm{~nm}$ in diameter), were found to circulate for longer than larger USPIO particles (over $50 \mathrm{~nm}$ ), and can be gradually taken up by the reticuloendothelial system in lymph tissue and bone marrow. Larger USPIO nanoparticles, named as SPIONs, are generally taken up quickly by the reticuloendothelial system in Kupffer cells of the liver, and have limited uptake in lymph and bone tissues (Briley-Saebo et al. 2004; Jain et al. 2008; Kim et al. 2006; Van Beers et al. 2001).

In comparison with iron oxide MNPs, the carbonencapsulated iron nanoplatform containing the iron 
core covered by a carbon coating has recently been found to alter complex intracellular signaling pathways, resulting in a cascade of possible toxic effects including apoptosis in human hepatoma cells (BEL7402) (Kai et al. 2011). Studies evidenced that the increase in apoptosis caused by CEINs was accompanied with the Bax over-expression, mitochondrial membrane potential decrease, and the release of cytochrome $\mathrm{C}$ from mitochondria into cytosol (Kai et al. 2011). Recent toxicological observations of different groups used for surface coatings and/or modification types in MNPs suggest that some functional groups such as hydroxyl $(-\mathrm{OH})$, carboxylic $(-\mathrm{COOH})$, amine $\left(-\mathrm{NH}_{2}\right)$, and citrate are especially critical determinants of cellular responses, degrees of cytotoxicity, and potential mechanisms of toxicity (Hong et al. 2011; Kai et al. 2011; Unfried et al. 2007). Surface functional groups $\left(-\mathrm{COOH}\right.$ or $\left.-\mathrm{NH}_{2}\right)$ also determined the toxic potential of graphene and carbon nanotubes (Jain et al. 2011; Singh et al. 2011). Moreover, carbon-based nanomaterials, such as graphene oxide sheets, have recently demonstrated to be really cytotoxic to the cells and have shown to induce thrombosis upon systemic administration to the animal (Singh et al. 2011). Interestingly, prothrombotic character of graphene oxide sheets was found to be dependent on surface charge distribution as reduced graphene oxide or amine-modified graphene was significantly less effective in aggregating platelets (Singh et al. 2012). To data, amine-modified singlewalled carbon nanotubes were also found to protect neurons from injury in rats (Lee et al. 2011). In addition to surface modifications in MNPs, some unique physicochemical properties of nanoparticles, such as shape and size might also play a critical role in producing cytotoxic effects, and plausibly influences aggregation states during in vitro examinations of MNPs and graphene nanoparticles in cell culture models (Akhavan et al. 2012; Hong et al. 2011). It was noted that iron oxide nanoparticles coated with negatively charged citrate ligands were destabilized in cell culture media and interacted strongly with human lymphoblastoid cells (Safi et al. 2011). Studies also evidence that interactions between iron oxide nanoparticles and living cells depend dramatically on the behavior of the nanoparticles in biological fluids. This observation was found in agreement with other recent findings, showing that iron oxide nanoparticles with negative charges on the surface were readily absorbed in cells via receptor-mediated cell endocytosis (Zhang et al. 2008). To our knowledge, by subtle modifying the surface of the CEINs and/or iron oxide nanoparticles, with different aliphatic or aromatic ligands, one plausibly can interfere with the delicate balance of the cellular homeostasis (Hong et al. 2011; Kai et al. 2011; Magrez et al. 2006; Unfried et al. 2007). Therefore, the side and the type of surface functional groups are crucial factors that plausibly determine the biological safety of CEINs, as these factors are hypothesized to be directly related to cytotoxicity, which are pivotal for in vivo practical applications such as DDS and targeted imaging in translation cancer research.

Cellular interaction of MNPs is one of the big challenges in recent nanotoxicology programs (Kim et al. 2012). Although a variety of studies dealing with the cytotoxicity of MNPs exist in recent literatures, so far, no such studies were concerned with CEINs and their cytotoxic effects on melanoma cells. Melanomas are the most aggressive skin cancers in humans, in part, due to their unique ability to rapidly invade the different tissue and organs, thus making anticancer therapy much more difficult (Evans et al. 2013). Melanoma mortality rates of 1.5 are similar in Central and Eastern Europe and Western Europe, although rates vary with a high of 3.2 in Norway and a low of 0.9 in Greece (Forsea et al. 2012). In general, rising incidence rates of cutaneous melanoma have been observed during the last four decades in white populations worldwide (Erdmann et al. 2013). This increase is reported to have leveled off recently in several Northern and Western European countries, Australia, New Zealand, and in North America.

In order to elucidate the CEIN-induced cytotoxicity and the potent mechanism(s) of such deleterious effects, if any due to surface modifications, nonfunctionalized and pre-functionalized CEINs composing of the modified carbon surface with surface acidic groups bearing different negative charges on the surface were synthesized in a lab scale. The asobtained CEINs were tested for comprehensive alternative cytotoxicity assays using human (HTB-140) and murine (B16-F10) melanoma cells. Normal human dermal fibroblasts (HDFs) were served as controls. In the light of recent data, especially cell membranes, mitochondria and nucleus have been considered the major cell compartments relevant for possible nanoparticle-induced toxicity (Unfried et al. 
2007). Therefore, a dose-response relationship of the carbon-coated iron nanomaterial was elucidated based on the cell membrane, mitochondrial, and nucleus targeted cytotoxicity endpoints (in vitro). The most important question raised in the present study is also whether there is a minimum set of physical and chemical characterization data for magnetic nanomaterials that is required for their realistic characterization in cytotoxicity studies. In the present study, therefore, a complete evaluation of the size, shape, and the surface characterization of CEINs was examined to support toxicity findings in both melanoma cancer and normal cells.

\section{Materials and methods}

Synthesis and characterization of carbon-

encapsulated iron nanoparticles

\section{Synthesis and surface modification}

CEINs were synthesized by a carbon arc route. The detailed procedure is described elsewhere (Borysiuk et al. 2008; Bystrzejewski et al. 2005). The synthesis method is based on sublimation of the heterogeneous anode containing iron $(\mathrm{Fe})$ and graphite $(\mathrm{C})$. These materials are transformed to the vapor phase congruently due to the very high temperature in the carbon arc $(5,000-6,000 \mathrm{~K})$. Next, the as-formed metalcarbon gas undergoes rapid cooling, which leads to nucleation and solidification of iron nanoparticles encapsulated in carbon cages. In brief, the carbon arc discharge was ignited between the graphite cathode and graphite anode, which was doped with $\mathrm{Fe}$ (45 wt $\%$ ). The discharge was maintained under $\mathrm{Ar}-\mathrm{H}_{2}$ atmosphere $(50: 50 \mathrm{vol} \%)$ at the total pressure of $60.0 \mathrm{kPa}$. The as-obtained raw product contained CEINs and non-encapsulated iron particles (Fe@C/ $\mathrm{Fe})$. A fraction of the $\mathrm{Fe} @ \mathrm{C} / \mathrm{Fe}$ sample was further subjected to a purification process to remove the nonencapsulated $\mathrm{Fe}$ particles $(\mathrm{Fe})$. The purification procedure included $24 \mathrm{~h}$ refluxing in boiling $3 \mathrm{M} \mathrm{HCl}$ with further washing in excess of water and ethanol, and drying in air at $70{ }^{\circ} \mathrm{C}$. The purified CEINs were also chemically oxidized to introduce surface acidic groups which are covalently bound to the carbon coatings. The corresponding product was noted as $\mathrm{Fe} @ \mathrm{C}-\mathrm{COOH}$. In a typical run, $2 \mathrm{~g}$ of the $\mathrm{Fe} @ \mathrm{C}$ product was suspended in a mixture containing $80 \mathrm{ml}$ of concentrated $\mathrm{H}_{2} \mathrm{SO}_{4}$ and $26 \mathrm{ml}$ of concentrated $\mathrm{HNO}_{3}$. The sample was sonicated in a water bath at $25{ }^{\circ} \mathrm{C}$ for $3 \mathrm{~h}(80 \mathrm{~W})$. Then, the suspension was diluted by 11 of distilled water and allowed to cool down for $2 \mathrm{~h}$. The suspended particles were recovered on a membrane filter under reduced pressure and washed with excess of water and ethanol. To obtain the Fe@ $\mathrm{C}-\mathrm{CH}_{2} \mathrm{CH}_{2}-\mathrm{COOH}$ sample, the organic acyl peroxides of dicarboxylic acids, $\mathrm{HOOC}\left(\mathrm{CH}_{2}\right)_{n}$ $\mathrm{C}(\mathrm{O}) \mathrm{OO}(\mathrm{O}) \mathrm{C}\left(\mathrm{CH}_{2}\right)_{n} \mathrm{COOH}(n=2,3)$ were used as a precursors of the so called "functional" radicals (Peng et al. 2003). Thermal decomposition of succinic acid peroxide resulted in the generation of 2-carboxyethyl radicals $\left({ }^{\circ} \mathrm{CH}_{2} \mathrm{CH}_{2}-\mathrm{COOH}\right)$. The radicals thus formed are very reactive and ready to functionalize the purified CEINs. The corresponding product was noted as $\mathrm{Fe} @ \mathrm{C}-\mathrm{CH}_{2} \mathrm{CH}_{2}-\mathrm{COOH}$. In brief, the purified (Fe@C) was dispersed in $o$-dichlorobenzene (SigmaAldrich) under inert atmosphere, heated to $150{ }^{\circ} \mathrm{C}$ and succinic acid acyl peroxide was added three times with $24 \mathrm{~h}$ intervals. After the reaction the carbon material was filtered through nylon filter, washed with $o$-dichlorobenzene, methanol, and acetone (all from Sigma-Aldrich). The crude material was then sonicated in concentrated $\mathrm{HCl}$ for $0.5 \mathrm{~h}$, filtered and washed with water until the eluate became neutral.

\section{Characterization}

The morphological details of the products were analyzed by transmission electron (TEM) microscopy. The diameter distribution was obtained by analyzing 100-120 objects on TEM images and then the respective histograms were plotted. The iron content was evaluated by thermogravimetry in an oxygen atmosphere. The point of zero charge was determined by the mass titration method (Noh and Schwarz 1989). The $\mathrm{pH}$ of a $20 \mathrm{ml} 0.01 \mathrm{M} \mathrm{NaCl}$ solution was adjusted to 10 by $\mathrm{NaOH}$ and $\mathrm{HCl}$. Then, CEIN samples were added successively in 10-50 mg increments and the resulting $\mathrm{pH}$ value was measured after reaching an equilibrate $\mathrm{pH}$ value (typically after 10-20 min). The solutions were magnetically stirred and purged with Ar. The point of zero charge was determined from the plateau in the plot of $\mathrm{pH}$ versus added mass (Supplementary Fig. S1). The measurements were done using a digital $\mathrm{pH}$-meter (Metrohm) calibrated with standard buffers (purchased from POCH Gliwice). The 
amounts of the surface acidic groups were determined by Boehm titration (Boehm 1994). The CEIN sample of mass ca. $200 \mathrm{mg}\left(\mathrm{Fe} @ \mathrm{C}-\mathrm{COOH}, \mathrm{Fe} @ \mathrm{C}-\left(\mathrm{CH}_{2}\right)_{2}-\right.$ $\mathrm{COOH})$ or $600 \mathrm{mg}(\mathrm{Fe} @ \mathrm{C} / \mathrm{Fe}, \mathrm{Fe} @ \mathrm{C})$ was added to a $50 \mathrm{ml}$ vial containing $25 \mathrm{ml}$ of the following solutions: $\mathrm{NaOH}, \mathrm{NaHCO}_{3}$, and $\mathrm{Na}_{2} \mathrm{CO}_{3}$ (each solution had the concentration of $0.05 \mathrm{M}$ ). The vials were tightly protected by a parafilm and shaked for $24 \mathrm{~h}$. Then, the CEINs were removed by a neodymium magnet and filtered. Aliquots $(5 \mathrm{ml})$ were titrated with $0.05 \mathrm{M} \mathrm{HCl}$ with continuous Ar purging. All titrations were performed in triplicate using a Metrohm Titrando automatic titrator. The amount of acidic groups was determined under the assumptions that carboxylic, lactonic, and phenolic groups are neutralized by $\mathrm{NaOH}$, carboxylic and lactonic groups are neutralized by $\mathrm{Na}_{2} \mathrm{CO}_{3}$, and carboxylic groups are neutralized by $\mathrm{NaHCO}_{3}$.

The surface charge density (SCD), which expresses the mean charge value over the global surface area, which is available to the surrounding environment, was calculated using the formula as follows:

$\mathrm{SCD}=\frac{\mathrm{TC} \cdot F}{\mathrm{SA}}\left[\mathrm{C} / \mathrm{m}^{2}\right]$

where TC is the total content of surface functional groups determined from Boehm titration $(\mathrm{mmol} / \mathrm{g})$, SA is specific surface area $\left(\mathrm{m}^{2} / \mathrm{g}\right)$, and $\mathrm{F}$ is Faraday constant $(96.5 \mathrm{C} / \mathrm{mmol})$. The specific surface area was evaluated from the nitrogen adsorption isotherms.

\section{Preparation of CEIN solutions for cytotoxicity studies}

In the present study, a purified water solution of carboxymethyl cellulose (CMC, Sigma-Aldrich) was used as a surfactant for CEINs. The stability of CMC suspensions of CEIN samples was evaluated by turbidimetry. The as-sonicated suspension of CEINs was immediately transferred to a quartz cuvette and the absorbance at $532 \mathrm{~nm}$ was monitored for $12 \mathrm{~h}$ with a step of 1 min using a spectrophotometer (Shimadzu 2401). The obtained absorbance versus time was then converted to concentration versus time curves. The influence of the CMC concentration on the sedimentation stability of CEIN suspensions was also investigated. Three tests were performed, in which the CMC concentration was $0.01,0.1$, and $1.0 \mathrm{mg} / \mathrm{ml}$. The highest stability was found for the largest $\mathrm{CMC}$ concentration. In this case the equilibrium concentration of suspended CEINs reached $79 \%$ of the initial concentration. The equilibrium concentration for suspensions prepared in the 0.1 and $0.01 \mathrm{mg} / \mathrm{ml} \mathrm{CMC}$ solutions was 71 and $60 \%$, respectively. In the cytotoxicity assay, however, the final $0.1 \mathrm{mg} / \mathrm{ml} \mathrm{CMC} \mathrm{solution} \mathrm{was} \mathrm{selected} \mathrm{to} \mathrm{prepare}$ suspensions of all studied CEIN samples, because its viscosity $(0.957 \mathrm{mPa} \mathrm{s})$ is comparable to the viscosity of pure water $(0.895 \mathrm{mPa} \mathrm{s})$. The viscosity of $1.0 \mathrm{mg} / \mathrm{ml} \mathrm{CMC}$ solution exceeds more than four times ( $3.863 \mathrm{mPa} \mathrm{s})$ the viscosity of water.

Cell culture

Human melanoma cells (HTB-140) and mouse melanoma cells (B16-F10) were used in experiments. Normal HDF was served as controls. All cell lines were obtained from Institute of Oncology (Gliwice, Poland). Frozen stock vials of the cells were thawed and used throughout. Cells were routinely cultured at $37{ }^{\circ} \mathrm{C}$ in a humidified atmosphere with $5 \% \mathrm{CO}_{2}$ in $75 \mathrm{~cm}^{2}$ flasks containing $10 \mathrm{ml}$ of Dulbecco's modified Eagle's medium (DMEM), supplemented with $10 \%$ fetal calf serum (FCS), 2 mM L-glutamine, $50 \mathrm{IU} / \mathrm{ml}$ penicillin, and $50 \mathrm{mg} / \mathrm{ml}$ streptomycin (all from GIBCO). The medium was changed every 3rd day. For subculture, the cells were washed twice with phosphate-buffered saline (PBS) and incubated with trypsin-ethylenediamine tetra-acetic acid (EDTA) solution $(0.25 \%$ trypsin, $1 \mathrm{mM}$ EDTA) for $2 \mathrm{~min}$ at $37{ }^{\circ} \mathrm{C}$ to detach the cells. Thereafter, the complete media were then added into the flask at room temperature to inhibit the effect of trypsin. The cells were washed twice by centrifugation and resuspended in the complete fresh media for reseeding and growing in new culture flasks or plates. Cells were counted using a hemocytometer.

\section{Cytotoxicity assays}

To study the cellular toxicity of the four type of CEINs, the surface non-modified ( $\mathrm{Fe} @ \mathrm{C} / \mathrm{Fe}$ and $\mathrm{Fe} @ \mathrm{C})$ and the surface modified (Fe@C-COOH and $\left.\mathrm{Fe} @ \mathrm{C}-\mathrm{CH}_{2} \mathrm{CH}_{2}-\mathrm{COOH}\right)$ samples were suspended in a purified water solution containing carboxymethyl cellulose $(0.01 \% \mathrm{CMC} \mathrm{w/v})$, which served as a surfactant, and then added to the cell culture media and used throughout in all experiments. Respective media used without nanomaterials were served as controls. 


\section{MTT reduction assay}

Cells were seeded on a 24-well plate (NUNC) at a density of $4 \times 10^{4}$ cells/well in $500 \mu$ of DMEM medium supplemented with $10 \%$ FCS and antibiotics (see above). After $24 \mathrm{~h}$ of incubation at $37{ }^{\circ} \mathrm{C}$ in $5 \%$ $\mathrm{CO}_{2}$ atmosphere, the cells were rinsed with the medium, and suspended with fresh medium. To study the cellular toxicity of CEINs, the surface modified and non-modified nanoparticles were added to the cell culture media at concentrations of $0.0001,0.001,0.01$, $0.1,1.0,5.0,10.0,50.0$, and $100.0 \mu \mathrm{g} / \mathrm{ml}$, respectively. In control cultures, the cells were placed in $500 \mu \mathrm{l}$ of the medium without MNPs and CMC at the same cell density. After $24 \mathrm{~h}$ of incubation at $37^{\circ} \mathrm{C}$, the nanoparticle suspension was removed, and the cells were washed twice with PBS, detached using trypsinEDTA solution, and the MTT solution $(0.5 \mathrm{mg} / \mathrm{ml}$ MTT in PBS) (Sigma-Aldrich) was added for $2 \mathrm{~h}$. Thereafter, the MTT solution was replaced with acidic isopropanol $(0.1 \mathrm{~N} \mathrm{HCl}$ in absolute isopropanol) (Sigma-Aldrich) to dissolve the resulting formazan crystals. Samples were centrifuged at 15,000 rpm for $10 \mathrm{~min}$. Absorbance values at $570 \mathrm{~nm}$ were measured within $1 \mathrm{~h}$ with a spectrophotometer (UVmini-1240, Shimadzu) after calibration to zero absorbance using acidic isopropanol. The untreated cells were used as a control. The relative cell viability $(\%)$ related to control wells containing cell culture medium without nanoparticles was calculated by the following equation: $[A$ (test sample) $/ A$ (control) $] \times 100 \%$ (where $A$ is absorbance).

\section{Lactate dehydrogenase (LDH) leakage assay}

The leakage of lactate dehydrogenase (LDH) in cells was determined using a cytotoxicity detection kit LDH (Roche). Initially, cells were seeded at a density of $4 \times 10^{4}$ cells/well in a 24 -well plate at $37^{\circ} \mathrm{C}$ and $5 \% \mathrm{CO}_{2}$ atmosphere in $500 \mu \mathrm{l}$ media per well (DMEM medium supplemented with $10 \%$ FCS and antibiotics). After $24 \mathrm{~h}$ stabilization of the cells, the medium in the wells was replaced with the fresh medium containing CEINs at concentrations of $0.0001,0.001,0.01,0.1,1.0,5.0,10.0,50.0$, and $100.0 \mu \mathrm{g} / \mathrm{ml}$, respectively (test CEIN samples). In low control cultures, the cells at the same cell density were placed in $500 \mu \mathrm{l}$ of medium without CEINs and CMC. In high control cultures, the cells at the same cell density were placed in $500 \mu \mathrm{l}$ of medium without CEINs and CMC with $15 \mu \mathrm{l} /$ well of Triton X-100 lysis solution (Sigma-Aldrich). Additional cell-free wells containing nanoparticles in the concentration range tested were prepared for subtraction of absorption effects. After $24 \mathrm{~h}$ exposure, cell culture medium from each well was carefully removed and centrifuged (4,000 rpm, $7 \mathrm{~min})$. Then, aliquots of supernatants $(100 \mu \mathrm{l})$ were transferred to fresh wells of 96-well plate and mixed with equal amounts of freshly prepared assay reaction mixture containing $30 \mu \mathrm{l}$ LDH assay solution supported by the assay kit. The microtiter plate was incubated for $30 \mathrm{~min}$ at room temperature in the dark as described by the manufacturer. The absorbance was measured at $490 \mathrm{~nm}$ with a microplate reader (BioTek, Synergy 4, Biokom) equipped with Gen5 software (BioTech Instruments, Inc., Biokom). The nanoparticle mediated cytotoxicity expressed as the LDH release (\%) was determined by the following equation: [ $A$ test sample $-A$ low control $) /(A$ high control $-A$ low control $)] \times 100 \%$ (where $A$ is absorbance).

\section{Annexin V and propidium iodide staining (apoptosis)}

Annexin-V binding was performed using an AnnexinV-FITC kit (Becton-Dickinson) as described by the manufacturer. To data, cells were seeded at a density of $4 \times 10^{4}$ cells/well in a 24 -well plate at $37{ }^{\circ} \mathrm{C}$ and $5 \% \quad \mathrm{CO}_{2}$ atmosphere in $500 \mu \mathrm{l}$ media (DMEM medium supplemented with $10 \%$ FCS and antibiotics) per well. After $24 \mathrm{~h}$ incubation of the cells, the medium in the wells was replaced with the fresh medium containing CEINs at concentrations of 0.001 and $1.0 \mu \mathrm{g} / \mathrm{ml}$, respectively. After $24 \mathrm{~h}$ exposure, the nanoparticle suspension was removed, and detached cells using trypsin-EDTA solution, were washed twice with cold PBS. Thereafter, the cells were then re-suspended in $1 \times$ binding buffer after which $100 \mu \mathrm{l}$ of solution was transferred to a $5 \mathrm{ml}$ culture tube. Annexin V-FITC $5 \mu \mathrm{l}$ and propidium iodide (PI) $5 \mu \mathrm{l}$ were added, and the cells were then incubated for $15 \mathrm{~min}$ at room temperature in the dark, after which $400 \mu \mathrm{L}$ of $1 \times$ binding buffer was added to each tube and analyzed in the BD FACS Calibur flow cytometer. Flow cytometry analyses were conducted on 5,000 cells in each case. Data analysis was performed with BD FACStation Software (Becton-Dickinson). Apoptosis was quantitatively confirmed by analyzing the 
percentage of early apoptotic cells using Annexin-VFITC/PI double staining.

\section{Calcein AM and propidium iodide staining (viability and necrosis)}

Calcein acetoxymethyl (Calcein AM) and PI staining was performed using a Calcein AM/PI kit (MoBiTec $\mathrm{GmbH}$, Germany) as described by the manufacturer. To data, cells were seeded at a density of $4 \times 10^{4}$ cells/ well in a 24-well plate at $37{ }^{\circ} \mathrm{C}$ and $5 \% \mathrm{CO}_{2}$ atmosphere in $500 \mu \mathrm{l}$ media (DMEM medium supplemented with $10 \%$ FCS and antibiotics) per well. After $24 \mathrm{~h}$ incubation of the cells, the medium in the wells was replaced with the fresh medium containing CEINs at concentrations of 0.001 and $1.0 \mu \mathrm{g} / \mathrm{ml}$ and incubated for $24 \mathrm{~h}$. After removing the culture medium and a gentle washing with PBS, the cells were stained with assay solution containing Calcein AM and PI $(2 \mu \mathrm{l} / \mathrm{ml}$ Calcein-AM and $1 \mu \mathrm{l} / \mathrm{ml} \mathrm{PI})$ and incubated at $37{ }^{\circ} \mathrm{C}$ for $15 \mathrm{~min}$. Digital images of viable (green fluorescence-excitation wavelength: $490 \mathrm{~nm}$, emission wavelength: $515 \mathrm{~nm}$ ) and dead (red fluorescence-excitation wavelength: $535 \mathrm{~nm}$, emission wavelength: $617 \mathrm{~nm}$ ) cells in selected areas were visualized using phasecontrast inverted microscopy (Nikon Eclipse TS 100F) equipped with Nikon Digital Sight DS-U2 camera.

\section{TEM analysis (internalization studies)}

Cells were seeded at a density of $4 \times 10^{4}$ cells/well in a 24-well plate at $37{ }^{\circ} \mathrm{C}$ and $5 \% \mathrm{CO}_{2}$ atmosphere in $500 \mu \mathrm{l}$ media (DMEM medium supplemented with $10 \%$ FCS and antibiotics) per well and allowed to attach for $24 \mathrm{~h}$. After $24 \mathrm{~h}$ incubation of the cells, the medium in the wells was replaced with the fresh medium containing CEINs at concentrations of $10 \mu \mathrm{g} / \mathrm{ml}$ and incubated for $24 \mathrm{~h}$. At the end of the exposure, the cells were washed twice with cold PBS and then they were collected and fixed with $2.5 \%$ glutaraldehyde (Serva) buffered in 0.1 M PBS overnight at $4{ }^{\circ} \mathrm{C}$. The samples were washed again with PBS, and post fixed in $1 \%$ osmium tetroxide (Serva) at $4{ }^{\circ} \mathrm{C}$ for $1 \mathrm{~h}$. After dehydration in series concentrations of ethanol and infiltration in acetone, cells were embedded in Epon 812 (Serva), and ultra-thin sections cut with glass knives were stained with uranyl acetate (Serva) and lead citrate (Serva), and viewed under JEM 1220 TEM (JEOL).
Statistical analysis

The data were expressed as mean \pm the standard deviation (SD) of three independent experiments. Wherever appropriate, the data were subjected to statistical analysis by one-way analysis of variance (ANOVA) followed by Dunnett's method for multiple comparisons. A value of $P<0.05$ was considered significant.

\section{Results}

The as-obtained raw (Fe@ $\mathrm{C} / \mathrm{Fe})$, purified (Fe@C), and surface-functionalized CEINs ( $\mathrm{Fe} @ \mathrm{C}-\mathrm{COOH}$ and $\mathrm{Fe} @ \mathrm{C}-\mathrm{CH}_{2} \mathrm{CH}_{2} \mathrm{COOH}$ ) have similar morphological features. They are composed of spheroidal nanoparticles with a typical core-shell structure, i.e., the metallic cores are tightly covered by a carbon coating (Fig. 1). Their diameter ranges between 5 and $140 \mathrm{~nm}$ (Fig. 1). The diameter distributions are presented in Fig. 2. Importantly, the greatest fraction of CEINs has the diameter 40 and $60 \mathrm{~nm}$. The mean diameter values obtained from the histograms are listed in Table 1. This parameter gradually decreases (from 56 to $46 \mathrm{~nm}$ ) for the purified and surface-functionalized CEINs. This finding indicates that purification and chemical modification result in irreversibly dissolving some of the pristine iron nanoparticles. It is supported in Fig. 1b-d, in which it is shown that some amounts of empty carbon encapsulates are present (examples of these nanostructures are arrowed).

The chemical treatment (purification or surface modification) of CEINs leads to substantial reduction of iron $(\mathrm{Fe})$ content (Table 1). In the case of Fe@C samples, the observed decrease is to the irreversible leaching of the Fe nanoparticles from the as-obtained product, which are not completely encapsulated in carbon and therefore these particles readily dissolve in an acid. In fact, it is consistent with a TEM image (Fig. 1b) showing some empty carbon encapsulates, which originally had the iron core. On the basis of the data from Table 1, one can state that ca. 28-29 \% Fe particles (in relation to the total Fe content) in the raw sample $\mathrm{Fe} @ \mathrm{C} / \mathrm{Fe}$ may have a direct contact with the surrounding environment (e.g., components of the biological fluids, cell membranes, etc.). This number is in good agreement with the observed weight loss after purification (33 wt \%, Table 1). The CEINs of the 

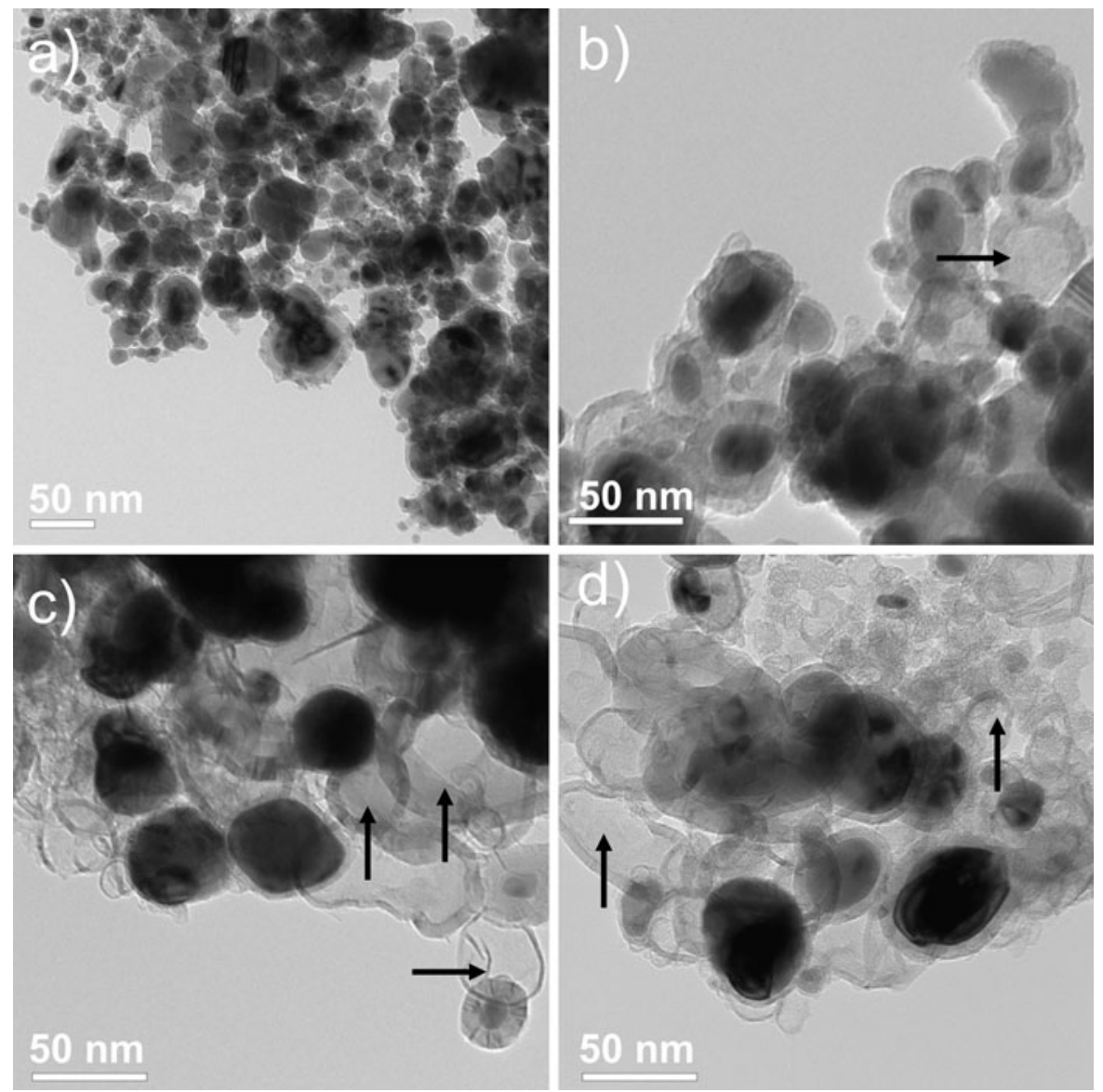

Fig. 1 TEM images of Fe@C/Fe (a), Fe@C (b), Fe@C-COOH (c) and Fe@C- $\left(\mathrm{CH}_{2}\right) \mathrm{COOH}(\mathbf{d})$. Carbon encapsulates with empty core are arrowed

sample Fe@C have very high stability in acid media and do not undergo subsequent leaching. The reference test has shown that 10 day storage of the purified CEINs (Fe@C) in concentrated $\mathrm{HCl}$ results in $4 \%$ mass loss only (data not shown). The $\mathrm{Fe}$ content in samples Fe@ $\mathrm{C}-\mathrm{COOH}$ and $\mathrm{Fe} @ \mathrm{C}-\mathrm{CH}_{2} \mathrm{CH}_{2} \mathrm{COOH}$ is lower in comparison with purified CEINs. In the case of CEINs functionalized via $\mathrm{H}_{2} \mathrm{SO}_{4} / \mathrm{HNO}_{3}$ treatment the decreased $\mathrm{Fe}$ content is due to the highly oxidizing power of the acids used. The treatment in $\mathrm{H}_{2} \mathrm{SO}_{4} /$ $\mathrm{HNO}_{3}$ mixture also destroys (to some degree) and perforates the carbon layers in these encapsulate, which have the thinnest coatings. Obviously, the perforation enables the leaching of the iron core and finally leads to the decreased Fe content. This finding is supported by a TEM image (Fig. 1c), which shows empty carbon encapsulates. The sample Fe@C$\mathrm{CH}_{2} \mathrm{CH}_{2} \mathrm{COOH}$ contains less $\mathrm{Fe}$ in comparison to the purified product $(\mathrm{Fe} @ \mathrm{C})$. This is an expectable finding, because the covalently attached linkers (37 wt \%) contribute to the total mass of the functionalized CEINs (Table 1). Interestingly, the surface functionalization by 2-carboxyethyl radicals is also accompanied by partial perforation of carbon coatings (Fig. 1d).

The results of Boehm titration and values of point of zero charge are presented in Table 2. The samples have substantially different surface chemistry features. The raw CEINs $(\mathrm{Fe} @ \mathrm{C} / \mathrm{Fe}$ ) have the lowest content of surface groups, which can be neutralized by the strong base $(\mathrm{NaOH})$. This sample has the point of zero charge of 7.4. The observed surface charge in $\mathrm{Fe} @ \mathrm{C} / \mathrm{Fe}$ may originate both from (i) partially oxidized non-encapsulated $\mathrm{Fe}$ nanoparticles and (ii) oxygen acidic sites on carbon coatings in CEINs. It should be noted that non-encapsulated Fe particles are 

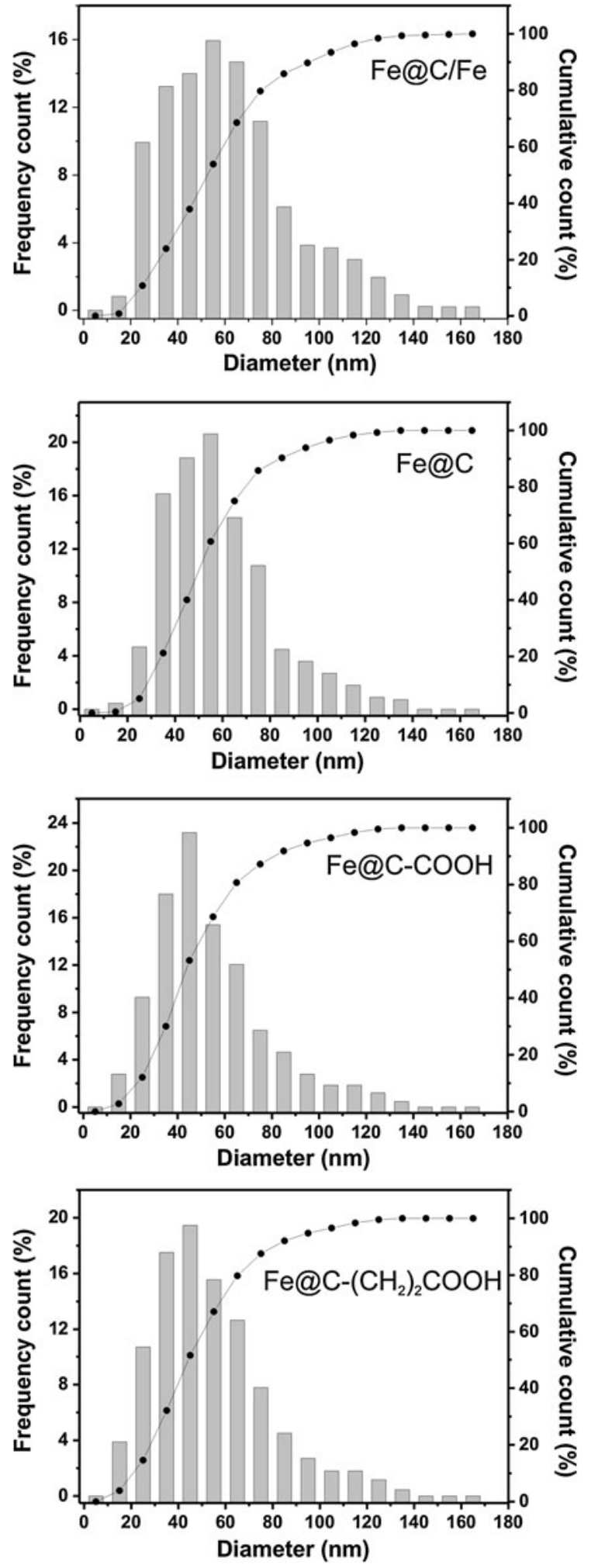

Fig. 2 Diameter distribution of carbon-encapsulated iron nanoparticles in continuous contact with the ambient atmosphere and may be oxidized. The measured value of the point of zero charge is significantly lower in comparison to the values reported for pure goethite $(\mathrm{FeO}(\mathrm{OH}) ; 9.4)$ (Kosmulski et al. 2003) and zero valent iron nanoparticles (Sun et al. 2006). This comparison supports the above hypothesis concerning that CEINs and nonencapsulated $\mathrm{Fe}$ nanoparticles contribute to the net surface charge. The surface of $\mathrm{Fe} @ \mathrm{C}, \mathrm{Fe} @ \mathrm{C}-\mathrm{COOH}$, and $\mathrm{Fe} @ \mathrm{C}-\left(\mathrm{CH}_{2}\right)_{2} \mathrm{COOH}$ has acidic sites. It is demonstrated by the point of zero charge values, which are lower than 7. Importantly, these samples differ greatly in the total content of surface acidic groups, which changes in the same order as the point of zero charge (Table 2). The smallest acidity $(0.16 \mathrm{mmol} / \mathrm{g})$ is found for the purified CEINs (Fe@C). Since this sample has not been subjected to surface functionalization, the acidic sites likely originate from oxygen, which could be bound during the synthesis process (e.g., from contaminations from the buffer gases). The surface modification using the $\mathrm{H}_{2} \mathrm{SO}_{4} / \mathrm{HNO}_{3}$ mixture increases the total acidity by 7 times. The greatest increase of the surface acidity (almost 16 times) is observed in Fe@ $\mathrm{C}-\left(\mathrm{CH}_{2}\right) \mathrm{COOH}$ sample. The distribution of acidic groups onto a surface of oxidized CEIN samples is slightly different. The carboxylic groups are the most abundant component of the total surface acidity and their relative fraction is 0.47 and 0.56 for $\mathrm{Fe} @ \mathrm{C}-\mathrm{COOH}$ and $\mathrm{Fe} @ \mathrm{C}-\left(\mathrm{CH}_{2}\right)_{2} \mathrm{COOH}$, respectively. The relative amount of lactonic- and phenolic-like groups in both samples is almost the same.

The stability of CMC $(0.1 \mathrm{mg} / \mathrm{ml})$ suspensions of CEIN samples was evaluated by turbidimetry before the cytotoxicity study. Importantly, in the case of sample Fe@C/Fe it was not possible to obtain a stable suspension, even for long $(>1 \mathrm{~h})$ sonication times. This drawback results from the highly hydrophobic character of sample $\mathrm{Fe} @ \mathrm{C} / \mathrm{Fe}$ (this sample contain uncoated Fe particles, which increase the hydrophobicity). For other CEIN samples, i.e., Fe@C, Fe@C$\mathrm{COOH}$, and $\mathrm{Fe} @ \mathrm{C}-\left(\mathrm{CH}_{2}\right)_{2} \mathrm{COOH}$, respectively, this problem was not observed. The time sedimentation curves are shown in Fig. 3. In each case the concentration gradually decreases with time. The highest drop $(75 \%)$ is observed for sample Fe@C. The functionalized CEINs (Fe@C-COOH, and Fe@C$\left.\left(\mathrm{CH}_{2}\right)_{2} \mathrm{COOH}\right)$ have substantially larger stability. The equilibrium concentration is of 70-75\% of the initial 
Table 1 Weight variation during purification, Fe content, specific surface area, and mean diameter

\begin{tabular}{lllll}
\hline CEINs & $\begin{array}{l}\text { Weight variation } \\
(\text { wt\% })\end{array}$ & $\begin{array}{l}\text { Fe content } \\
(\mathrm{wt} \%)\end{array}$ & $\begin{array}{l}\text { Surface area } \\
\left(\mathrm{m}^{2} / \mathrm{g}\right)\end{array}$ & $\begin{array}{l}\text { Mean diameter } \\
(\mathrm{nm})\end{array}$ \\
\hline $\mathrm{Fe} @ \mathrm{C} / \mathrm{Fe}$ & N.A. & 69 & 60 & 56 \\
$\mathrm{Fe} @ \mathrm{C}$ & -33 & 50 & 77 & 52 \\
$\mathrm{Fe} @ \mathrm{C}-\mathrm{COOH}$ & -47 & 40 & 95 & 46 \\
$\mathrm{Fe} @ \mathrm{C}-\left(\mathrm{CH}_{2}\right)_{2} \mathrm{COOH}$ & +37 & 35 & 75 & 47 \\
\hline
\end{tabular}

$\mathrm{Fe} @ \mathrm{C} / \mathrm{Fe}$ the raw CEINs containing carbon-coated iron and uncoated iron particles, $\mathrm{Fe} @ \mathrm{C}$ the purified Fe@C/Fe due to removing the uncoated iron particles; $\mathrm{Fe} @ \mathrm{C}-\mathrm{COOH}$ the Fe@C oxidized in $\mathrm{H}_{2} \mathrm{SO}_{4} / \mathrm{HNO}_{3}, \mathrm{Fe} @ \mathrm{C}-\mathrm{CH}_{2} \mathrm{CH} \mathrm{H}_{2} \mathrm{COOH}$ Fe@C functionalized by attack of 2-carboxyethyl $\left(\mathrm{CH}_{2} \mathrm{CH}_{2} \mathrm{COOH}\right)$ radicals

Table 2 Point of zero charge, results of boehm titration, surface charge density, and average density of surface acidic groups (D)

\begin{tabular}{llllllll}
\hline CEINs & $\begin{array}{l}\text { Point } \\
\text { of zero } \\
\text { charge }\end{array}$ & $\begin{array}{l}\text { Total content } \\
\text { of functional } \\
\text { groups }(\mathrm{mmol} / \mathrm{g})\end{array}$ & $\begin{array}{l}\text { Carboxylic } \\
\text { groups } \\
(\mathrm{mmol} / \mathrm{g})\end{array}$ & $\begin{array}{l}\text { Lactonic } \\
\text { groups } \\
(\mathrm{mmol} / \mathrm{g})\end{array}$ & $\begin{array}{l}\text { Phenolic } \\
\text { groups } \\
(\mathrm{mmol} / \mathrm{g})\end{array}$ & $\begin{array}{l}\text { Surface } \\
\text { charge } \\
\text { density }\left(\mathrm{C} / \mathrm{m}^{2}\right)\end{array}$ & $\begin{array}{l}\mathrm{D} \text { [groups/ } \\
\text { hexagon] }\end{array}$ \\
\hline $\mathrm{Fe} @ \mathrm{C} / \mathrm{Fe}$ & 7.42 & 0.05 & $<\mathrm{LOD}$ & $<\mathrm{LOD}$ & $<\mathrm{LOD}$ & 0 & 0 \\
$\mathrm{Fe} @ \mathrm{C}$ & 6.71 & 0.16 & 0.02 & 0.06 & 0.08 & 0.20 & 0.21 \\
$\mathrm{Fe} @ \mathrm{C}-\mathrm{COOH}$ & 4.50 & 1.11 & 0.53 & 0.30 & 0.28 & 1.12 & 1.20 \\
$\mathrm{Fe} @ \mathrm{C}-\left(\mathrm{CH}_{2}\right)_{2} \mathrm{COOH}$ & 4.18 & 2.51 & 1.42 & 0.59 & 0.50 & 3.23 & 3.43 \\
\hline
\end{tabular}

Data are mean $(n=3)$, the observed relative deviation was not greater than $5 \%$

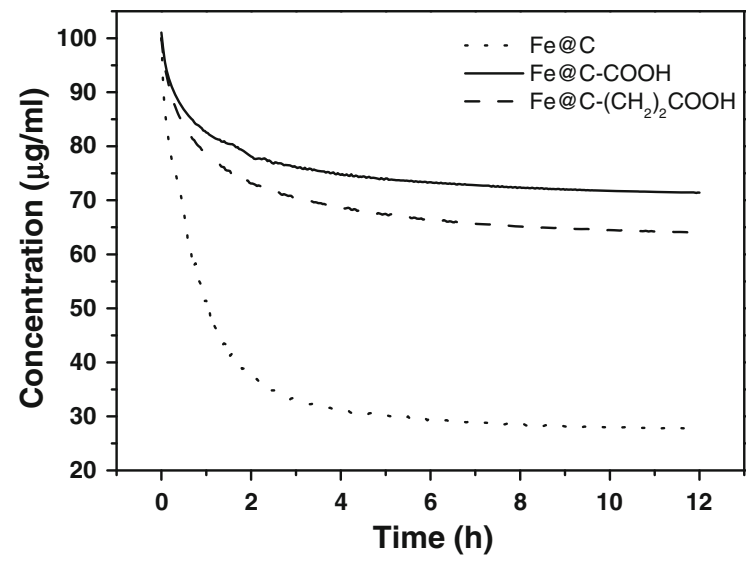

Fig. 3 Time sedimentation curves of water CMC $(0.1 \mathrm{mg} / \mathrm{ml})$ dispersions of Fe@C, Fe@C-COOH, and Fe@C- $\left(\mathrm{CH}_{2}\right)_{2} \mathrm{COOH}$ nanoparticles

concentration. This effect is undoubtedly caused by the presence of surface functional groups, which increase the hydrophilicity and improve the interactions with the surfactant.

The results demonstrate that all four types of CEINs were able to affect the viability of normal and cancer cells in different patterns. After $24 \mathrm{~h}$ treated with a raw
CEIN material (Fe@C/Fe) at $1-100 \mu \mathrm{g} / \mathrm{ml}$ different concentration, the viability of human and murine melanoma cells decreased as determined by MTT reduction assays (Figs. 4, 5). The studies show that only doses of 50 and $100 \mu \mathrm{g} / \mathrm{ml}$ were enabled to diminish the viability of normal HDFs (Fig. 6). In both human and murine cancer cells, a quite similar profile of the viability was observed when the purified sample Fe@C was introduced at the two large doses (Figs. 4, 5). It should be noted, however, that murine melanoma cells were found to be more sensitive to the sample $\mathrm{Fe} @ \mathrm{C}$ as compared to that of the human ones (Fig. 5). In contrast to normal human fibroblasts, the CEINs functionalized via $\mathrm{H}_{2} \mathrm{SO}_{4} / \mathrm{HNO}_{3}$ treatment, showed more diminished effects on the cell survival in human and murine melanoma cells (Figs. 4, 5, 6). In general, these patterns were also observed when the carbon surface of the CEINs has been modified by attack of 2-carboxyethyl ( $\mathrm{CH}_{2} \mathrm{CH}_{2} \mathrm{COOH}$ ) radicals (Figs. 4, 5).

After $24 \mathrm{~h}$ exposure at varying doses of CEINs, LDH leakages resulted in a different dose-dependent pattern depends on the cell line type and the nanoparticle type and concentrations in medium (Figs. 7, 8, 9). In our results, CEINs with or without surface 


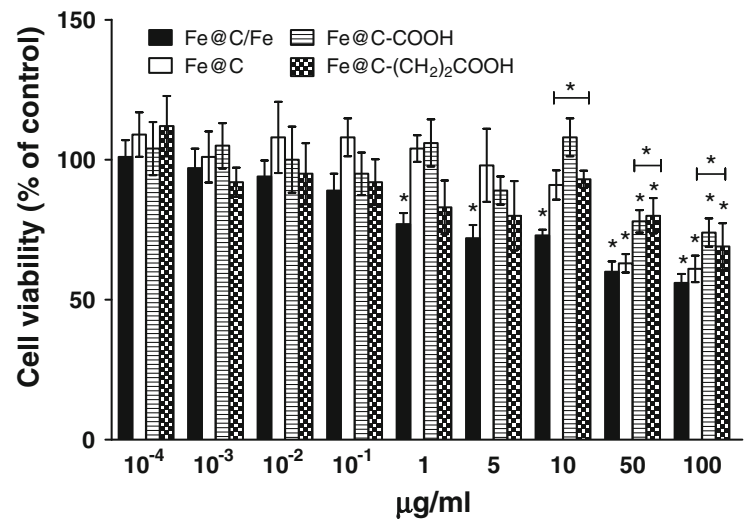

Fig. 4 Effect of carbon-encapsulated magnetic nanoparticles on mitochondrial function in human melanoma (HTB-140) cells. Cell viability was determined by MTT reduction assay after $24 \mathrm{~h}$ of exposure to CEINs $(0.0001-100 \mu \mathrm{g} / \mathrm{ml})$. Data are mean \pm SD. Significant ANOVA test among different CEIN types versus $\mathrm{Fe} @ \mathrm{C} / \mathrm{Fe}$ is represented by bracket with a asterisk over each data set $(P<0.05)$, asterisk above nanomaterial columns indicates statistically significant difference compared to untreated controls $(P<0.05)$. See Table 1 for CEINs labeling

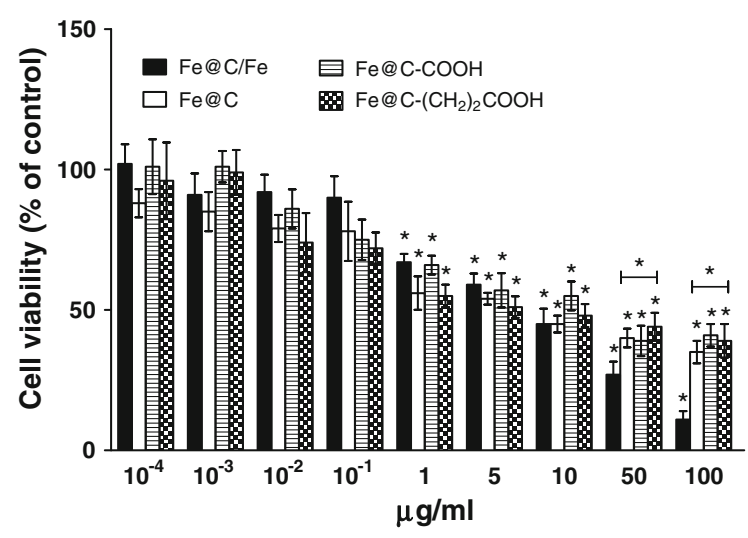

Fig. 5 Effect of carbon-encapsulated magnetic nanoparticles on mitochondrial function in murine melanoma (B16-F10) cells. Cell viability was determined by MTT reduction assay after $24 \mathrm{~h}$ of exposure to CEINs $(0.0001-100 \mu \mathrm{g} / \mathrm{ml})$. Data are mean \pm SD. Significant ANOVA test among different CEIN types versus $\mathrm{Fe} @ \mathrm{C} / \mathrm{Fe}$ type is represented by bracket with a asterisk over each data set $(P<0.05)$, asterisk above nanomaterial columns indicates statistically significant difference compared to untreated controls $(P<0.05)$. See Table 1 for CEINs labeling

functional groups elucidated quite similar profiles in LDH leakage assays on human and murine cancer cells (Figs. 7, 8). However, the release of LDH in murine cancer cells exposed to all type of CEINs was higher than that in human cancer cells (Figs. 7, 8).

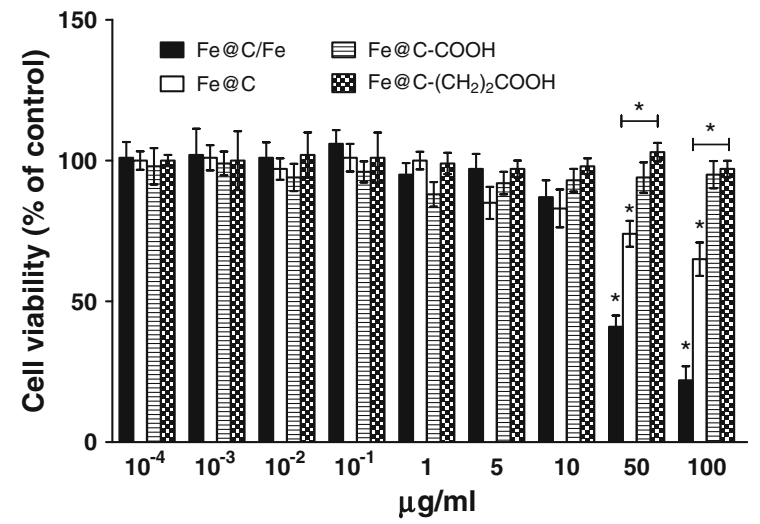

Fig. 6 Effect of carbon-encapsulated magnetic nanoparticles on mitochondrial function in human dermal fibroblasts (HDFs). Cell viability was determined by MTT reduction assay after $24 \mathrm{~h}$ of exposure to CEINs $(0.0001-100 \mu \mathrm{g} / \mathrm{ml})$. Data are mean \pm SD. Significant ANOVA test among different CEIN types versus $\mathrm{Fe} @ \mathrm{C} / \mathrm{Fe}$ type is represented by bracket with a asterisk over each data set $(P<0.05)$, asterisk above nanomaterial columns indicates statistically significant difference compared to untreated controls $(P<0.05)$. See Table 1 for CEINs labeling

Interestingly, the LDH release profile in HDFs exposed to all fore type of CEINs were around $5 \%$ at the concentration of $0.0001-50 \mu \mathrm{g} / \mathrm{ml}$, respectively (Fig. 9). When the CEINs concentrations increased up to $100 \mu \mathrm{g} / \mathrm{ml}$, the increased level of LDH release was observed (Fig. 9). This membrane effect of CEINs was also studied using a Calcein AM/PI double staining method, which mainly describes on cell viability due to membrane permeability assays. In accordance with data from both MTT reduction and LDH leakage assays, the results of our studies also confirm that PI positive staining was slightly increased in human melanoma cells (data not shown), and especially, in murine cancer cells exposed to all four type of CEINs that evidenced that a number of such cells are expected to be damaged or dead in $24 \mathrm{~h}$-post treatment period (Fig. 10). PI is a fluorescent vital dye that stains DNA. It does not cross the plasma membrane of cells that are viable or in the early stages of apoptosis because they maintain plasma membrane integrity. In contrast those cells in the late stages of apoptosis or already dead have lost plasma membrane integrity and are permeable to PI (Fig. 10).

To assess the extent and mode of early or late apoptotic events induced by CEINs with or without acidic groups on the carbon surface, Annexin-Vfluorescein isothiocyanate (Annexin-V-FITC) and PI 


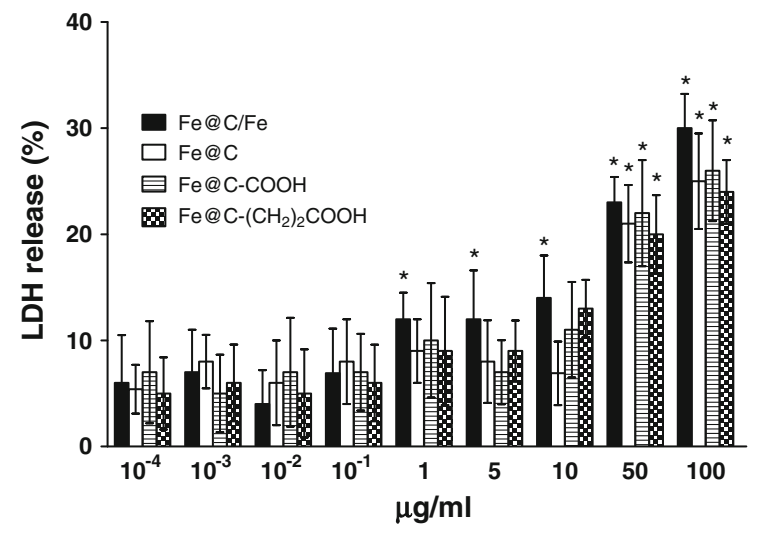

Fig. 7 Effect of carbon-encapsulated magnetic nanoparticles on LDH leakage in human melanoma (HTB-140) cells. Cytotoxicity was determined by LDH release after $24 \mathrm{~h}$ of exposure to CEINs $(0.0001-100 \mu \mathrm{g} / \mathrm{ml})$. Data are mean \pm SD. Asterisk above nanomaterial columns indicates statistically significant difference compared to untreated controls $(P<0.05)$. See Table 1 for CEINs labeling

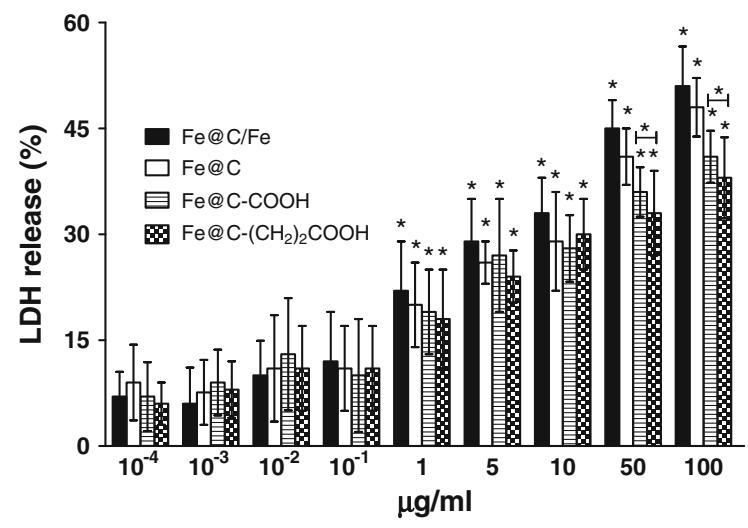

Fig. 8 Effect of carbon-encapsulated magnetic nanoparticles on LDH leakage in murine melanoma (B16-F10) cells. Cytotoxicity was determined by LDH release after $24 \mathrm{~h}$ of exposure to CEINs $(0.0001-100 \mu \mathrm{g} / \mathrm{ml})$. Data are mean \pm SD. Significant ANOVA test among different CEIN types versus $\mathrm{Fe} @ \mathrm{C} / \mathrm{Fe}$ type is represented by bracket with a asterisk over each data set $(P<0.05)$, asterisk above nanomaterial columns indicates statistically significant difference compared to untreated controls $(P<0.05)$. See Table 1 for CEINs labeling

double staining was performed using a FACS method in studies. To data, the externalization of phosphatidylserine (PS), which is localized commonly on the outer cellular membrane, was monitored as a key step in early stage apoptosis. Annexin-V which has a strong calcium-dependent affinity for PS was applied to determine the apoptotic rate of the tested cells in

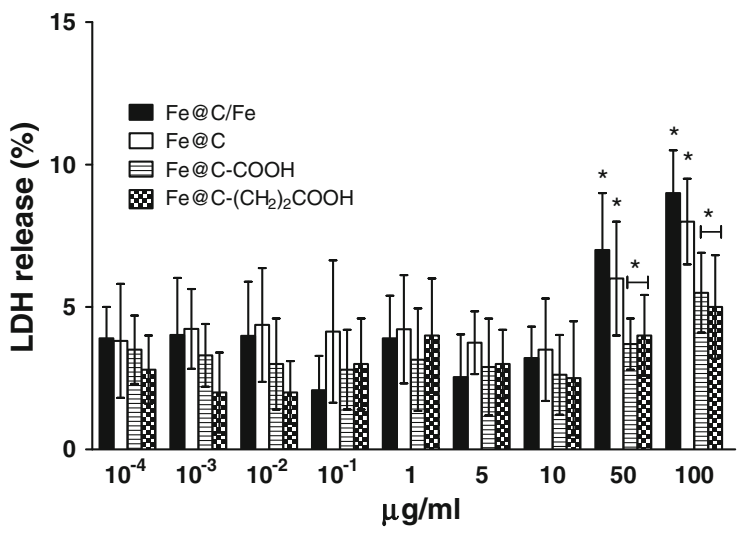

Fig. 9 Effect of carbon-encapsulated magnetic nanoparticles on LDH leakage in human dermal fibroblasts (HDFs). Cytotoxicity was determined by LDH release after $24 \mathrm{~h}$ of exposure to CEINs $(0.0001-100 \mu \mathrm{g} / \mathrm{ml})$. Data are mean \pm SD. Significant ANOVA test among different CEIN types versus Fe@C/Fe type is represented by bracket with a asterisk over each data set $(P<0.05)$, asterisk above nanomaterial columns indicates statistically significant difference compared to untreated controls $(P<0.05)$. See Table 1 for CEINs labeling

response to the treatment of CEINs. In the present study, the Annexin-V(-)/PI(-) cell population was regard as normal cells, while positive staining just for Annexin- $\mathrm{V}(+)$ but negative staining for $\mathrm{PI}(-)$ was nominated as a measure of early apoptosis, and Annexin- $\mathrm{V}(+) / \mathrm{PI}(+)$ was nominated to late apoptosis or necrosis. As shown in Fig. 11a, compared with the untreated control of human melanoma cells, a significant increase in the ratio of early apoptosis cells was observed in both raw CEINs and purified CEINs with or without carboxylic groups, respectively. Murine melanoma cells were found to be more sensitive to prone late apoptosis or necrosis events (Figs. 10, 11b) as compared to that of human melanoma cells (Fig. 11a) and of normal HDFs, respectively (Fig. 11c).

Our TEM studies clearly evidenced that all kinds of CEINs were incorporated into melanoma cells after $24 \mathrm{~h}$ incubation at $10 \mu \mathrm{g} / \mathrm{ml}$. As shown in Fig. 12a, b the purified CEINs (Fe@C) were distributed both as single nanoparticles and conglomerates on the cell membrane and inside of cell penetrating within the organelles such as nucleus and mitochondria. In B16F10 cells showed a large body of chromatin condensation, typical of apoptotic cell death, and plenty of swollen mitochondria (Fig. 12c). Treating with functionalized CEINs $\left(\mathrm{Fe} @ \mathrm{C}-\left(\mathrm{CH}_{2}\right) \mathrm{COOH}\right)$ also induced 


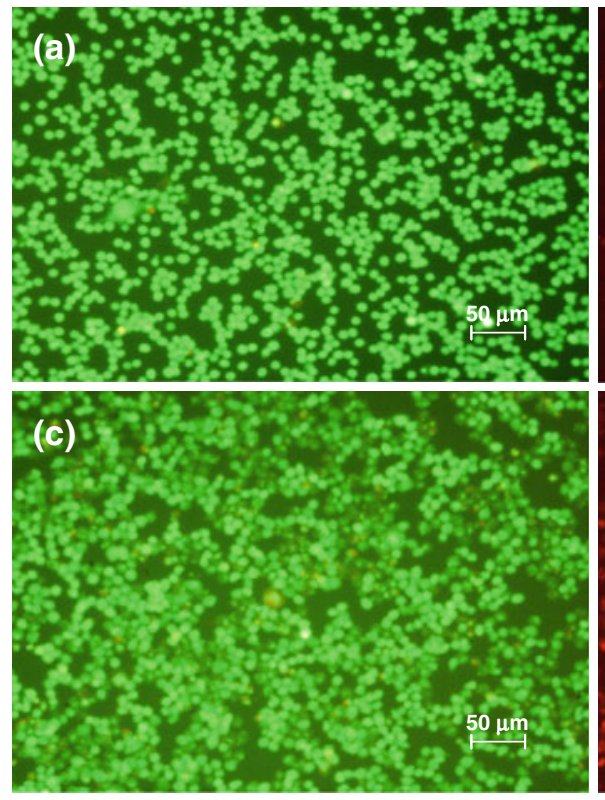

Fig. 10 Representative fluorescence images of murine melanoma (B16-F10) cells. Green images $\left(\lambda_{\mathrm{ex}}=490 \mathrm{~nm}\right)$ represent cells stained by acetoxymethyl calcein, and red images

internalization of iron nanomaterials in melanoma cells (Fig. 12d).

\section{Discussion}

Preclinical studies evidence that malignant cells are more prone to internalize the MNPs than normal cells (Fisichella et al. 2010; Saltan et al. 2011). The reason is that malignant cells possess a higher endocytotic potential than that of normal cells due to their enhanced requirement for nutrients in virtue of their high metabolic activity and proliferation rate (Clement et al. 2006; Zhang et al. 2009). Recent data also suggest that once the MNPs are located onto the cellular surface in cancer cells, fast internalization probably begins (Dam et al. 2012; Lu et al. 2012; Raoof et al. 2012). This was found in agreement with our findings presenting a number of internalizations in melanoma cells incubated with CEINs. To data, our theoretical calculation of the SCD revealed that both $\mathrm{Fe} @ \mathrm{C}-\mathrm{COOH}$ and $\mathrm{Fe} @ \mathrm{C}-\mathrm{CH}_{2} \mathrm{CH}_{2}-\mathrm{COOH}$ have a large electrical surface charge as compared to the purified Fe@C samples in physiological $\mathrm{pH}$, respectively (Table 1). The $\mathrm{pH}$ value of the PBS buffer (7.4) significantly exceeds the point of zero charge in the
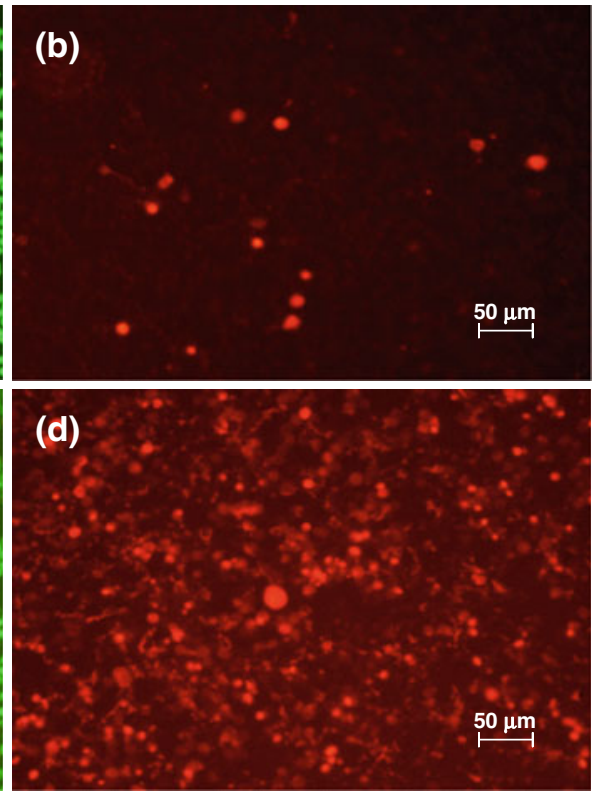

$\left(\lambda_{\mathrm{ex}}=545 \mathrm{~nm}\right)$ represent cells stained by propidium iodide. Control untreated cells $(\mathbf{a}, \mathbf{b})$, and $\mathrm{Fe} @ \mathrm{C}-\mathrm{COOH}$ treated cells (c, d) at $1 \mu \mathrm{g} / \mathrm{ml}$ for $24 \mathrm{~h}$. (Color figure online)

purified and surface functionalized CEINs. Importantly, the raw CEINs do not carry the surface charge, because their point of zero charge is almost the same as the $\mathrm{pH}$ of the PBS buffer. The SCD is therefore a really valuable parameter in nanoparticle cell studies, which express the mean charge value over the global surface area which is available to the surrounding environment (cell/medium). The surface area (in $\mathrm{m}^{2} / \mathrm{g}$ ) values are typical for the non-porous sorbents and vary between 60 and $95 \mathrm{~m}^{2} / \mathrm{g}$ for all CEINs samples. The calculated SCD changes in the same order as the surface acidity (Table 2). To present these data more clearly, one can say that the individual CEIN particle from the sample $\mathrm{Fe} @ \mathrm{C}-\mathrm{CH}_{2} \mathrm{CH}_{2}-$ $\mathrm{COOH}$ statistically has three times larger number of surface acidic groups in comparison with the sample $\mathrm{Fe} @ \mathrm{C}-\mathrm{COOH}$, respectively. Hence, the surface acidic groups get the negatively charged when CEINs $(\mathrm{COOH}) n$ are in contact with cell membranes in the culture medium. To data, it is also possible to evaluate the average density of surface acidic groups in respective CEINs. This density can be expressed as an average number of surface groups per one hexagon in a graphitic lattice (the carbon coating in CEINs is built of curved graphene layers). The $D$ values are shown in Table 2 . The density of surface acidic groups 

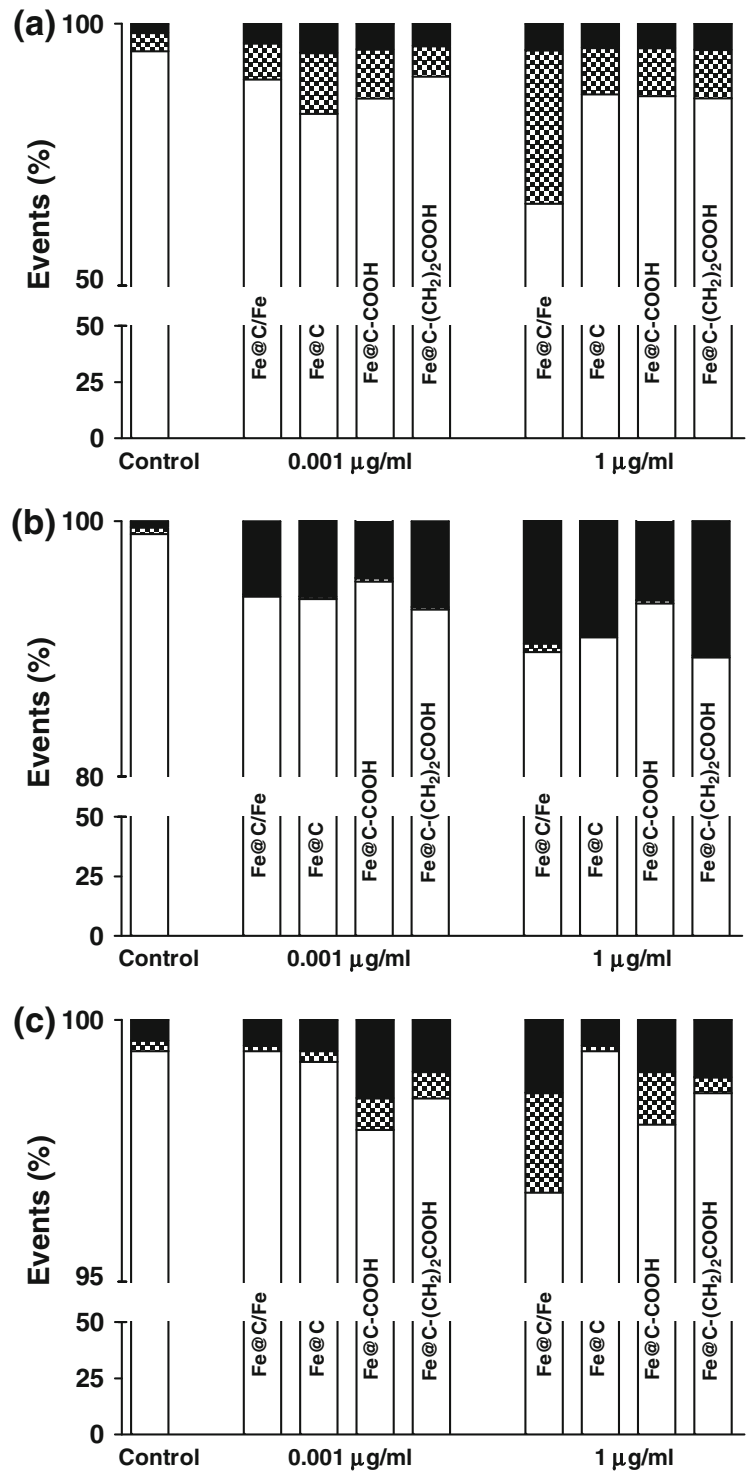

Fig. 11 Flow cytometric analysis of human melanoma HTB140 (a), murine melanoma B16-F10 (b), and human dermal fibroblasts HDFs (c). Cells were exposed to carbon-encapsulated iron nanoparticles for $24 \mathrm{~h}$. Cells were double staining with Annexin V-FITC and propidium iodide, and then fixed and analyzed on a flow cytometer. White bars life cells, dashed bars early apoptosis, black bars late apoptosis or necrosis

increases with an increase of the total surface acidity and changes in the same order as the SCD. The density of surface acidic groups in sample $\mathrm{Fe} @ \mathrm{C}-\left(\mathrm{CH}_{2}\right)_{2} \mathrm{COOH}$ is the highest and in this case 3-4 ligands are attached to one hexagon in graphitic lattice.

In our conducted research, the MTT assay was used to measure the basic cytotoxicity of CEINs in melanoma and normal cells of the dermal origin. Interestingly, incubation of human normal dermal fibroblasts with non-functionalized raw iron nanoparticles produced significant loss in viability of about 55 and $75 \%$ observed only at higher concentrations of 50 and $100 \mu \mathrm{g} / \mathrm{ml}$, respectively. Below this concentration (0.0001-10 $\mu \mathrm{g} / \mathrm{ml})$, cellular metabolic activity did not change as much as in comparison with unaffected control (Fig. 6). In contrast, all iron nanoparticles affected the metabolic activity in concentrationdependent manner, but in different patterns, when they were added at the concentration range of $1-100 \mu \mathrm{g} / \mathrm{ml}$ to the cancer (melanoma) cells. In general, the cytotoxicity of CEINs has been increased in relation to increasing concentration, as shown in Figs. 4 and 5. Surface modified iron nanoparticles (Fe@C-COOH and $\mathrm{Fe} @ \mathrm{C}-\mathrm{CH}_{2} \mathrm{CH}_{2}-\mathrm{COOH}$ ) revealed weak cytotoxic effects to both human normal fibroblasts and human melanoma cells, as well, and they remained around $80-100 \%$ viable. These samples decreased the viability of the murine cancer cells to about $40-60 \%$ depending on the increased nanoparticle concentration in the medium.

In our cytotoxicity studies, carbon-encapsulated iron nanoparticles with surface acidic groups are found to be more hydrophilic forms than that of the non-functionalized CEINs. In contrast to raw and purified CEINs without surface functional groups, they show significantly higher cell-survival rates in all cells exposed at doses of 50 and $100 \mu \mathrm{g} / \mathrm{ml}$ but their toxicity plausibly depends highly on the magnitude of the surface charge. Recent data evidenced that hydrophilic surfaces of nanoparticles, such as dextran, polyethylene glycol, polyethylene oxide, poloxamers, polysorbates, and polyoxamines provide a dynamic "cloud" of hydrophilic and neutral chains at the nanoparticle surface (Chiappetta et al. 2011; Gillich et al. 2011; Karmali et al. 2012). In other studies the significant role of surface charge (both positive and negative) and nanomaterial type on the uptake and biocompatibility of nanoparticles was discussed (Chen et al. 2011; Sohaebuddin et al. 2010). It should be noted that the MNP uptake by cells due to the vesicular transport-based cell endocytosis could be considered as a binding process followed by an internalization process (Zhang et al. 2008). To explain this phenomenon, Zeta potential measurements have been utilized in studying the interaction between normal breast epithelium cells (MCF10A) and cancer breast 


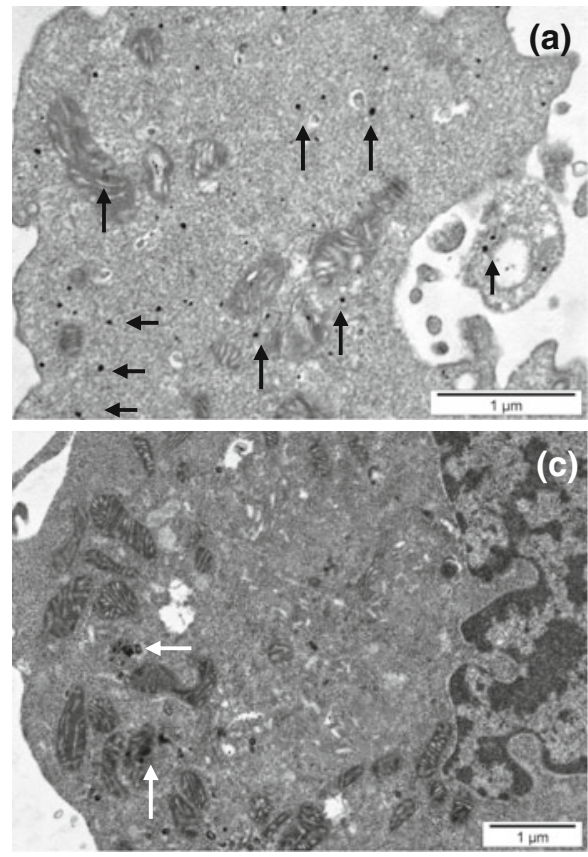

Fig. 12 Representative TEM images of murine melanoma (B16-F10) cells exposed to carbon-encapsulated iron nanoparticles at $10 \mu \mathrm{g} / \mathrm{ml}$ for $24 \mathrm{~h}$. Arrows show Fe@C (a, b, c) and

epithelium (MCF7) after incubation with iron oxide nanoparticles for different regiments of treatments (Zhang et al. 2008). The changes in Zeta potential values were found to be relative to cell surface charge, nanoparticle surface charge, and the interaction between cells and iron oxide nanoparticles (Zhang et al. 2008). Although, we did not measure directly the Zeta potential value of the respective CEIN sample(s) as well as normal and cancer (melanoma) cells studied to data, a battery of alternative cytotoxicity tests including LDH leakage assays following Annexin V-FITC/PI and Calcein AM/PI labeling were applied for all the four types of carbon-encapsulated iron nanomaterials to study CEIN-related membrane cytotoxicity effects due to differences in SCD. Interestingly, in the present study, "subtle" differences in cytotoxicity effects between both non-modified and surface modified CEINs possessing surface acidic groups were noted in normal dermal fibroblasts and melanoma cancer cells. These results clearly support Zhang et al. (2008) observations that Zeta potential and SCD (present data) parameters could really affect internalization processes and therefore might play a role in cytotoxicity effects of MNPs in cells.

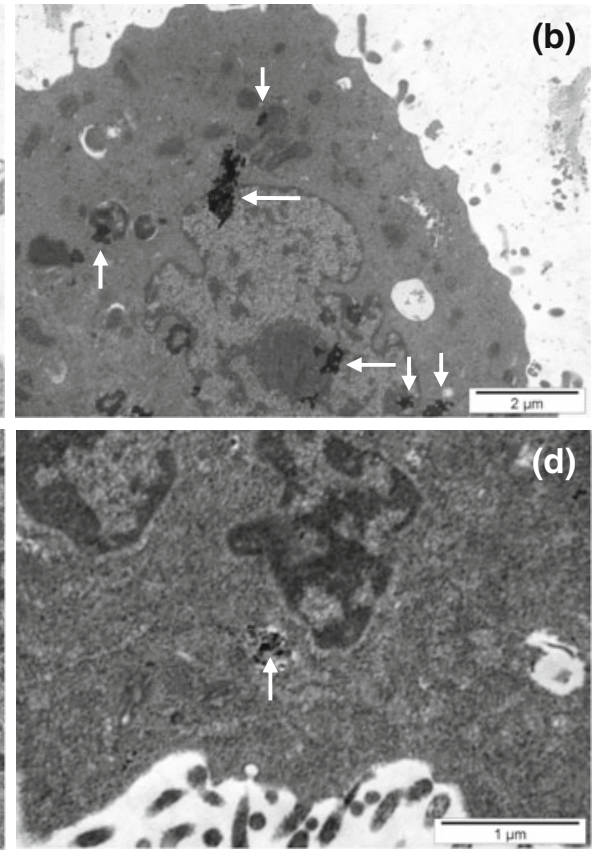

Fe@ $-\mathrm{CH}_{2} \mathrm{CH}_{2} \mathrm{COOH}$ (d) nanoparticles internalized in different cellular compartments and organelles such as cytoplasma and mitochondria $(\mathbf{a}, \mathbf{c})$ and nucleus $(\mathbf{b}, \mathbf{d})$

The LDH leakage assay relies on the membrane permeability of the cytosolic enzyme (lactic dehydrogenase) and represents a parameter for the cell integral stability. In the plasma membrane of the damaged or dead cells, the released LDH transfers lactate to pyruvate with co-reaction of $\mathrm{NAD}^{+}$to NADH transition, and then the oxidation reaction of NADH to $\mathrm{NAD}^{+}$due to diaphorase transfers the $\mathrm{H} / \mathrm{H}^{+}$from $\mathrm{NADH} / \mathrm{H}^{+}$to the tetrazolium salt, which is reduced to a formazan dye. In the LDH leakage assay, the amount of color formed is proportional to the number of lysed cells. Interestingly, viable cells produce negligible formazan dye signal with LDH leakage assay. The LDH leakage assay measures the signal of membranedamaged cells, not the live normal ones. Therefore, even though the cell number is increasing as incubation time is $24 \mathrm{~h}$, the LDH leakage assay cannot count the viability of live ones, but only detect the accumulated LDH derived from continuous leakage of damaged cells which number is proportional to the time. From the results of the LDH leakage test, we observed that all types of carbon-encapsulated iron nanoparticles induced different changes in normal and cancer cells, thereby suggesting that both human and 
murine melanoma cancer cells as well as human normal dermal fibroblasts probably had responded in different patterns to internalize the nanoparticles via cell membranes. Based upon the results of externalization of PS, which is localized commonly on the outer cellular membrane in cells, Annexin- $\mathrm{V}$ was also applied to determine the apoptotic rate of the tested cells in response to the treatment of CEINs. Analysis of Annexin V-FITC/PI stained cells by flow cytometry allows quantitation of the fraction of cells that are Annexin V-negative and propidium iodide-negative (double negative), Annexin V-positive and propidium iodide-negative (single positive), or Annexin V-positive and propidium iodide-positive (double positive). In the present study, human melanoma cells were found to be more sensitive to prone early apoptosis events due to CEINs as compared to that of murine melanoma cells as well as normal HDFs. In flow cytometry results, the population of Annexin V-positive live cells in the human melanoma cancer cell line increased, and most $(29.3 \%)$ of the cells became Annexin V-positive at $24 \mathrm{~h}$ at a concentration of $1 \mu \mathrm{g} / \mathrm{ml}$ for the raw CEIN sample (Fe@ $\mathrm{C} / \mathrm{Fe}$ ). Interestingly, our results with Calcein AM/PI double staining also evidenced that especially murine melanoma cells respond in late apoptosis/necrosis patterns when dosed with CEINs. These both observations were found in agreement with flow cytometry studies (Fig. 11b) and other recent reports in which MNPs such as iron oxides and carbon-encapsulated iron nanoforms promoted both early and late apoptotic events in different cancer cell lines (Kai et al. 2011; Saltan et al. 2011; Xia et al. 2011). Realizing the future clinical potential of these novel magnetic nanoplatforms as new contrast drug candidates in mMRI, a more through approach has to be done to better understand their cytotoxic insults at the molecular level in details.

\section{Conclusion}

The significance of this work is to elucidate subtle differences in cytotoxic effects between CEINs used as raw and purified materials, of which the carbon surface was functionalized with surface acidic groups. Results clearly demonstrate that CEINs plausibly interact with some mitochondrial and cell membranes as examined by MTT and LDH leakage assays and
TEM analysis as well. Our flow cytometry studies with double staining (Annexin-V-FITC/PI) of normal and melanoma cells also evidenced that early apoptosis events are trigged when the raw and purified CEIN materials are used in both human cancer and normal cells. Results show that CEIN-cell interactions plausibly depend on the surface aspects of the magnetic nanomaterial, which may be described according to their surface chemistry, hydrophilic/hydrophobic characteristics, or SCD. The final conclusions on particular CEIN material-type pattern toxicities should be viewed very carefully due to the complexity of the mechanism(s) determining the potent interactions at the CEIN-melanoma cell interfaces. Therefore, further detail studies on carbon-encapsulated iron nanoparticles containing modified surface with specific bio-ligands such as monoclonal antibodies or peptides targeting specific molecular receptors in cells are needed to determine the cancer cell behavior on contact with CEINs. More through approaches have to be also done to study CEINs in preclinical animal cancer models.

Acknowledgments This research was supported by the National Science Centre Grant N N518 381737.

Conflict of interest The authors declare that there are no conflicts of interest.

Open Access This article is distributed under the terms of the Creative Commons Attribution License which permits any use, distribution, and reproduction in any medium, provided the original author(s) and the source are credited.

\section{References}

Ahmed N, Fessi H, Elaissari A (2012) Theranostic applications of nanoparticles in cancer. Drug Discov Today 17(17-18): 928-934

Akhavan O, Ghaderi E, Akhavan A (2012) Size-dependent genotoxicity of graphene nanoplatelets in human stem cells. Biomaterials 33(32):8017-8025

Berman SMC, Walczak P, Bulte JWM (2011) Tracking stem cells using magnetic nanoparticles. Nanomed Nanobiotechnol 3:343-355

Boehm HP (1994) Some aspects of the surface chemistry of carbon blacks and other carbons. Carbon 32:759-769

Borysiuk J, Grabias A, Szczytko J, Bystrzejewski M, Twardowski A, Lange H (2008) Structure and magnetic properties of carbon encapsulated Fe nanoparticles obtained by arc plasma and combustion synthesis. Carbon 46:1693-1701

Briley-Saebo K, Bjørnerud A, Grant D, Ahlstrom H, Berg T, Kindberg GM (2004) Hepatic cellular distribution and 
degradation of iron oxide nanoparticles following single intravenous injection in rats: implications for magnetic resonance imaging. Cell Tissue Res 316:315-323

Bystrzejewski M, Huczko A, Lange H (2005) Arc plasma route to carbon-encapsuled magnetic nanoparticles for biomedical applications. Sens Actuators B-Chem 109:81-85

Bystrzejewski M, Cudziło S, Huczko A, Lange H, Soucy G, Cota-Sanchez G, Kaszuwara W (2007) Carbon encapsulated magnetic nanoparticles for biomedical applications: thermal stability studies. Biomol Eng 24:555-558

Bystrzejewski M, Klingeler R, Gemming T, Büchner B, Rümmeli MH (2011) Synthesis of carbon-encapsulated iron nanoparticles by pyrolysis of iron citrate and poly(vinyl alcohol): a critical evaluation of yield and selectivity. Nanotechnology 22(31):315606

Chen L, Mccrate JM, Lee JC, Li H (2011) The role of surface charge on the uptake and biocompatibility of hydroxyapatite nanoparticles with osteoblast cells. Nanotechnology 22(10): 105708

Chiappetta DA, Facorro G, de Celis ER, Sosnik A (2011) Synergistic encapsulation of the anti-HIV agent efavirenz within mixed poloxamine/poloxamer polymeric micelles. Nanomedicine 7:624-637

Clement JH, Schwalbe M, Buske N, Wagner K, Schnabelrauch M, Gornert P, Kliche KO, Pachmann K, Weitschies W, Hoffken K (2006) Differential interaction of magnetic nanoparticles with tumor cells and peripheral blood cells. J Cancer Res Clin Oncol 132:287-292

Dam DH, Lee JH, Sisco PN, Co DT, Zhang M, Wasielewski MR, Odom TW (2012) Direct observation of nanoparticlecancer cell nucleus interactions. ACS Nano 6:3318-3326

Davis MA, Zuckerman JE, Choi H, Seligson D, Tolcher A, Alabi CA, Yen Y, Heidel JD, Ribas A (2010) Evidence of RNAi in humans from systemically administered siRNA via targeted nanoparticles. Nature 464(7291):1067-1070

Erdmann F, Lortet-Tieulent J, Schüz J, Zeeb H, Greinert R, Breitbart EW, Bray F (2013) International trends in the incidence of malignant melanoma 1953-2008 are recent generations at higher or lower risk? Int J Cancer 132(2):385-400

Evans MS, Madhunapantula SV, Robertson GP, Drabick JJ (2013) Current and future trials of targeted therapies in cutaneous melanoma. Adv Exp Med Biol 779:223-255

Fisichella M, Dabboue H, Bhattacharyya S, Lelong G, Saboungi ML, Warmont F, Midoux P, Pichon C, Guérin M, Hevor T, Salvetat JP (2010) Uptake of functionalized mesoporous silica nanoparticles by human cancer cells. J Nanosci Nanotechnol 10:2314-2324

Forsea AM, Del Marmol V, de Vries E, Bailey EE, Geller AC (2012) Melanoma incidence and mortality in Europe: new estimates, persistent disparities. Br J Dermatol 167(5): 1124-1130

Gillich T, Benetti EM, Rakhmatullina E, Konradi R, Li W, Zhang A, Schlüter AD, Textor M (2011) Self-assembly of focal point oligo-catechol ethylene glycol dendrons on titanium oxide surfaces: adsorption kinetics, surface characterization, and nonfouling properties. J Am Chem Soc 133:10940-10950

Grass RN, Athanassiou EK, Stark WJ (2007) Covalently functionalized cobalt nanoparticles as a platform for magnetic separations in organic synthesis. Angew Chem Int Ed Engl 46(26):4909-4912
Gupta AK, Gupta M (2005) Cytotoxicity suppression and cellular uptake enhancement of surface modified magnetic nanoparticles. Biomaterials 26:1565-1573

Hong SH, Lee JH, Lee J, Kim HY, Park JY, Cho J, Lee J, Han DW (2011) Subtle cytotoxicity and genotoxicity differences in superparamagnetic iron oxide nanoparticles coated with various functional groups. Int J Nanomedicine 6:3219-3231

Hosseinkhani H (2006) DNA nanoparticles for gene delivery to cells and tissue. Int J Nanotechnol 3(4):416-461

Hosseinkhani H, Hong PD, Shyong YR, Ickowicz D, Farber IY, Domb AJ (2012) Development of 3D in vitro platform technology to engineer mesenchymal stem cells. Int J Nanomedicine 7:3035-3043

Jain TK, Reddy MK, Morales MA, Leslie-Pelecky DL, Labhasetwar V (2008) Biodistribution, clearance, and biocompatibility of iron oxide magnetic nanoparticles in rats. Mol Pharm 5:316-327

Jain S, Thakare VS, Das M, Godugu C, Jain AK, Mathur R, Chuttani K, Mishra AK (2011) Toxicity of multiwalled carbon nanotubes with end defects critically depends on their functionalization density. Chem Res Toxicol 24(11):2028-2039

Kai W, Xiaojun X, Ximing P, Zhenqing H, Qiqing Z (2011) Cytotoxic effects and the mechanism of three types of magnetic nanoparticles on human hepatoma BEL-7402 cells. Nanoscale Res Lett 6:480. doi:10.1186/1556-276X6-480

Karmali PP, Chao Y, Park JH, Sailor MJ, Ruoslahti E, Esener SC, Simberg D (2012) Different effect of hydrogelation on antifouling and circulation properties of dextran-iron oxide nanoparticles. Mol Pharm 9:539-545

Kim JS, Yoon TJ, Yu KN, Kim BG, Park SJ, Kim HW, Lee KH, Park SB, Lee JK, Cho MH (2006) Toxicity and tissue distribution of magnetic nanoparticles in mice. Toxicol Sci 89:338-347

Kim JE, Shin JY, Cho MH (2012) Magnetic nanoparticles: an update of application for drug delivery and possible toxic effects. Arch Toxicol 86(5):685-700

Kosmulski M, Maczka E, Jartych E, Rosenholmb JB (2003) Synthesis and characterization of goethite and goethitehematite composite: experimental study and literature survey. Adv Colloid Interface Sci 103:57-76

Lee HJ, Park J, Yoon OJ, Kim HW, Lee do Y, Kim do H, Lee WB, Lee NE, Bonventre JV, Kim SS (2011) Amine-modified single-walled carbon nanotubes protect neurons from injury in a rat stroke model. Nat Nanotechnol 6(2):121-125

Liu G, Swierczewska M, Lee S, Chen X (2010) Functional nanoparticles for molecular imaging guided gene delivery. Nano Today 5:524-539

Lu YJ, Wei KC, Ma CC, Yang SY, Chen JP (2012) Dual targeted delivery of doxorubicin to cancer cells using folateconjugated magnetic multi-walled carbon nanotubes. Colloids Surf B Biointerfaces 89:1-9

Magrez A, Kasas S, Salicio V, Pasquier N, Seo JW, Celio M, Catsicas S, Schwaller B, Forró L (2006) Cellular toxicity of carbon-based nanomaterials. Nano Lett 6:1121-1125

Miele E, Spinelli GP, Miele E, Fabrizio ED, Ferretti E, Tomao S, Gulino A (2012) Nanoparticle-based delivery of small interfering RNA: challenges for cancer therapy. Int J Nanomedicine 7:3637-3657 
Naqvi S, Samim M, Abdin M, Ahmed FJ, Maitra A, Prashant C, Dinda AK (2010) Concentration-dependent toxicity of iron oxide nanoparticles mediated by increased oxidative stress. Int J Nanomedicine 5:983-989

Noh JS, Schwarz JA (1989) Estimation of the point of zero charge of simple oxides by mass titration. J Colloid Interface Sci 130:157-164

Novotna B, Jendelova P, Kapcalova M, Rossner P, Turnovcova K, Bagryantseva Y, Babic M, Horak D, Sykova E (2012) Oxidative damage to biological macromolecules in human bone marrow mesenchymal stromal cells labeled with various types of iron oxide nanoparticles. Toxicol Lett 210:53-63

Pan D, Lanza GM, Wickline SA, Caruthers SD (2009) Nanomedicine: perspective and promises with ligand-directed molecular imaging. Eur J Radiol 70:274-285

Park JK, Jung J, Subramaniam P, Shah BP, Kim C, Lee JK, Cho JH, Lee C, Lee KB (2011) Graphite-coated magnetic nanoparticles as multimodal imaging probes and cooperative therapeutic agents for tumor cells. Small 7:1647-1652

Peng H, Alemany LB, Margrave JL, Khabashesku VN (2003) Sidewall carboxylic acid functionalization of single-walled carbon nanotubes. J Am Chem Soc 125:15174-15182

Poplawska M, Zukowska GZ, Cudzilo S, Bystrzejewski M (2010) Chemical functionalization of carbon-encapsulated magnetic nanoparticles by 1,3-dipolar cycloaddition of nitrile oxide. Carbon 48:1318-1320

Raoof M, Mackeyev Y, Cheney MA, Wilson LJ, Curley SA (2012) Internalization of C60 fullerenes into cancer cells with accumulation in the nucleus via the nuclear pore complex. Biomaterials 33:2952-2960

Safi M, Courtois J, Seigneuret M, Conjeaud H, Berret JF (2011) The effects of aggregation and protein corona on the cellular internalization of iron oxide nanoparticles. Biomaterials 32:9353-9363

Saltan N, Kutlu HM, Hur D, Iscan A, Say R (2011) Interaction of cancer cells with magnetic nanoparticles modified by methacrylamido-folic acid. Int J Nanomedicine 6:477-484

Schlachter EK, Widmer HR, Bregy A, Lönnfors-Weitzel T, Vajtai I, Corazza N, Bernau VJ, Weitzel T, Mordasini P, Slotboom J, Herrmann G, Bogni S, Hofmann H, Frenz M, Reinert M (2011) Metabolic pathway and distribution of superparamagnetic iron oxide nanoparticles: in vivo study. Int J Nanomedicine 6:1793-1800

Shubayev V, Pisanic T, Jin S (2009) Magnetic nanoparticles for theragnostics. Adv Drug Deliv Rev 61(6):467-477

Singh SK, Singh MK, Nayak MK, Kumari S, Shrivastava S, Grácio JJ, Dash D (2011) Thrombus inducing property of atomically thin graphene oxide sheets. ACS Nano 5(6):4987-4996

Singh SK, Singh MK, Kulkarni PP, Sonkar VK, Grácio JJ, Dash D (2012) Amine-modified graphene: thrombo-protective safer alternative to graphene oxide for biomedical applications. ACS Nano 6(3):2731-2740

Sohaebuddin SK, Thevenot PT, Baker D, Eaton JW, Tang L (2010) Nanomaterial cytotoxicity is composition, size, and cell type dependent. Part Fibre Toxicol 7:1-17

Subramani K, Hosseinkhani H, Khraisat A, Hosseinkhani M, Pathak Y (2009) Targeting nanoparticles as drug delivery systems for cancer treatment. Curr Nanosci 5:134-140

Sun YP, Li XQ, Cao J, Zhang WX, Wang HP (2006) Characterization of zero-valent iron nanopartciles. Adv Colloid Interface Sci 120:47-56
Taylor A, Krupskaya Y, Kramer Y, Fussel S, Klingeler R, Buchner B, Wirth MP (2010) Cisplatin-loaded carbonencapsulated iron nanoparticles and their in vitro effects in magnetic fluid hyperthermia. Carbon 48:2327-2334

Tietze R, Lyer S, Dürr S, Alexiou C (2012) Nanoparticles for cancer therapy using magnetic forces. Nanomedicine (Lond) 7:447-457

Tomitaka A, Hirukawa A, Yamada T, Morishita S, Takemura Y (2009) Biocompatibility of various ferrite nanoparticles evaluated by in vitro cytotoxicity assays using HeLa cells. J Mag Magn Mater 321:1482-1484

Unfried K, Albrecht C, Klotz LO, Von Mikecz A, Grether-Beck S, Schins RPF (2007) Cellular responses to nanoparticles: target structures and mechanisms. Nanotoxicology 1: $52-71$

Van Beers BE, Sempoux C, Materne R, Delos M, Smith AM (2001) Biodistribution of ultrasmall iron oxide particles in the rat liver. J Magn Reson Imaging 13:594-599

Xia G, Chen B, Ding J, Gao C, Lu H, Shao Z, Gao F, Wang X (2011) Effect of magnetic $\mathrm{Fe}_{3} \mathrm{O}_{4}$ nanoparticles with 2-methoxyestradiol on the cell-cycle progression and apoptosis of myelodysplastic syndrome cells. Int J Nanomedicine 6:1921-1927

Xie J, Lee S, Chen X (2010) Nanoparticle-based theranostic agents. Adv Drug Deliv Rev 62:1064-1079

Xu H, Cheng L, Wang C, Ma X, Li Y, Liu Z (2011) Polymer encapsulated upconversion nanoparticle/iron oxide nanocomposites for multimodal imaging and magnetic targeted drug delivery. Biomaterials 32:9364-9373

Ying E, Hwang HM (2010) In vitro evaluation of the cytotoxicity of iron oxide nanoparticles with different coatings and different sizes in A3 human T lymphocytes. Sci Total Environ 408:4475-4481

Yoo D, Lee JH, Shin TH, Cheon J (2011) Theranostic magnetic nanoparticles. Acc Chem Res 44:863-874

Yu MK, Park J, Jon S (2012) Targeting strategies for multifunctional nanoparticles in cancer imaging and therapy. Theranostics 2(1):3-44

Yuan Y, Rende D, Altan CL, Bucak S, Ozisik R, Borca-Tasciuc DA (2012) Effect of surface modification on magnetization of iron oxide nanoparticle colloids. Langmuir 28(36): 13051-13059

Zeng YY, Chen HJ, Shiau KJ, Hung SU, Wang YS, Wu CC (2012) Efficient enrichment of phosphopeptides by magnetic $\mathrm{TiO}_{2}$-coated carbon-encapsulated iron nanoparticles. Proteomics 12:380-390

Zhang Y, Yang M, Portney NG, Cui D, Budak G, Ozbay E, Ozkan M, Ozkan CS (2008) Zeta potential: a surface electrical characteristic to probe the interaction of nanoparticles with normal and cancer human breast epithelial cells. Biomed Microdevices 10:321-328

Zhang S, Li J, Lykotrafitis G, Bao G, Suresh S (2009) Sizedependent endocytosis of nanoparticles. Adv Mater 21: 419-424

Zhu MT, Wang Y, Feng WY, Wang B, Wang M, Ouyang H, Chai ZF (2010) Oxidative stress and apoptosis induced by iron oxide nanoparticles in cultured human umbilical endothelial cells. J Nanosci Nanotechnol 10:8584-8590 